\title{
Effects of phyto-oestrogens on tissues
}

\author{
John J. B. Anderson*, Mary Anthony, Mark Messina and Sanford C. Garner \\ Department of Nutrition, Schools of Public Health and Medicine, University of North Carolina, \\ Chapel Hill, NC 27599-7400, USA
}

\begin{abstract}
Recent investigations on the effects of phyto-oestrogens on various tissues have revealed that these diverse molecules may improve human health, particularly by protecting against certain chronic diseases. After a brief examination of the food sources, structures, and general cellular actions of the major phyto-oestrogens, current research findings on cardiovascular disease, skeletal tissues, and reproductive cancers are reviewed. Phytooestrogen concentrations in blood may be maintained at high levels in those consuming soyabean (Glycine max)-based food daily at several meals and exert their effects on target cells through either genomic effects via the classical oestrogen receptors or non-genomic effects mediated by membrane-bound oestrogen receptors or other cellular proteins. The expression of oestrogen receptor (OR) subtypes alpha $(\alpha)$ and beta $(\beta)$ varies across tissues, and cells that preferentially express OR- $\beta$, which may include bone cells, are more likely to respond to phyto-oestrogens. Conversely, reproductive tissues contain relatively more OR- $\alpha$ and may, thus, be differently affected by phyto-oestrogens. Soyabean phytooestrogens appear to prevent the progression of atherosclerosis through multiple interactions, including lowering of plasma lipids and lipoproteins, increased vasodilatation and, possibly, decreased activation of blood platelets and vascular smooth muscle cells. However, a favourable impact on cardiovascular disease morbidity and mortality by a soyabean-enriched western-type diet remains to be shown, and unresolved questions remain regarding dose and form of the phyto-oestrogens in relation to risks and benefits. The isoflavones of soyabean have been shown consistently to have bone-retentive effects in animal studies by several investigators using rodent models, although intakes must be above a relatively high threshold level for a lengthy period of time, and little or no extra benefit is observed with intakes above this threshold level. The reports of modest or no effects on prevention of bone loss in human and non-human primate studies respectively, may be due to the limited doses tested so far. The relationship between soyabean-food intake and cancer risk has been more extensively investigated than for any other disease, but with less certainty
\end{abstract}

\footnotetext{
Abbreviations: MNV, N-nitroso-N-methylurea; OR, oestrogen receptor; ORE, oestrogen response element; OVX, ovariectomized; SORM, selective oestrogen receptor modulator.

*Corresponding author: Dr J. Anderson, fax 001919966 7216, email jjb_anderson@unc.edu
} 
about the benefits of long-term consumption of phyto-oestrogen-containing foods on prevention of cancer. The observations that breast and prostate cancer rates are lower in Asian countries, where soyabean foods are consumed at high levels, and the high isoflavone content of soyabeans have led to examination of the potential protective effects of phytooestrogens. Establishing diet-cancer relationships has proved difficult, in part because of the conflicting data from various studies of effects of soyabean-diets on cancer. Epidemiological evidence, though not impressive, does suggest that soyabean intake reduces breast cancer risk. The isoflavone genistein has a potent effect on breast cancer cells in vitro, and early exposure of animals to genistein has been effective in reducing later development of mammary cancer. Thus, continuous consumption of soyabean foods in early life and adulthood may help explain the low breast cancer mortality rates in Asian countries. Although the evidence for a protective effect against prostate cancer may be slightly more supportive, more research is needed before any firm conclusions can be made about the phyto-oestrogen-cancer linkages.

\section{Phyto-oestrogens: Soyabean : Cancer: Bone: Blood lipids}

\section{Introduction}

Practically all plant foods contain small amounts of the diverse phyto-oestrogen molecules that have the potential to improve health. Phyto-oestrogens, especially the soyabean-derived isoflavones, are receiving great scrutiny as food supplements for the purposes of both enhancing the health of tissues and preventing several common diseases, such as cardiovascular diseases, cancers of reproductive tissues, and osteoporosis. Food phyto-oestrogen molecules can be divided into two major chemical classes: isoflavones and coumestans. The isoflavones are found predominantly in soyabeans (Glycine max), whereas coumestans are produced primarily by clovers (genus Trifolium) and some legumes. These molecules function as antioxidants in plants, but in mammalian tissues these natural products act as agonists, or partial agonists, of oestrogens.

This review covers the following topics relating to phyto-oestrogens: food sources, general cellular actions, effects on cardiovascular and skeletal tissues, and cancer chemoprevention.

\section{Food sources of phyto-oestrogens}

Relatively few foods contribute significant amounts of phyto-oestrogens to the human diet, and the cultural variation in consumption of those foods, particularly soyabean products, results in a wide range of intakes of these molecules. The use of soyabean products in Asian nations contributes to the highest levels of phyto-oestrogens measured in human subjects, e.g. Japanese men and women have intakes that are ten-fold or greater than those of the USA population average (Adlercreutz et al. 1993; Messina, 1995).

Phyto-oestrogens, both isoflavones and coumestans, are present in a variety of legumes consumed by Americans. The highest concentration of the major isoflavones (genistein and daidzein) are found in soyabeans and soyabean products as shown in Fig. 1 for genistein and 


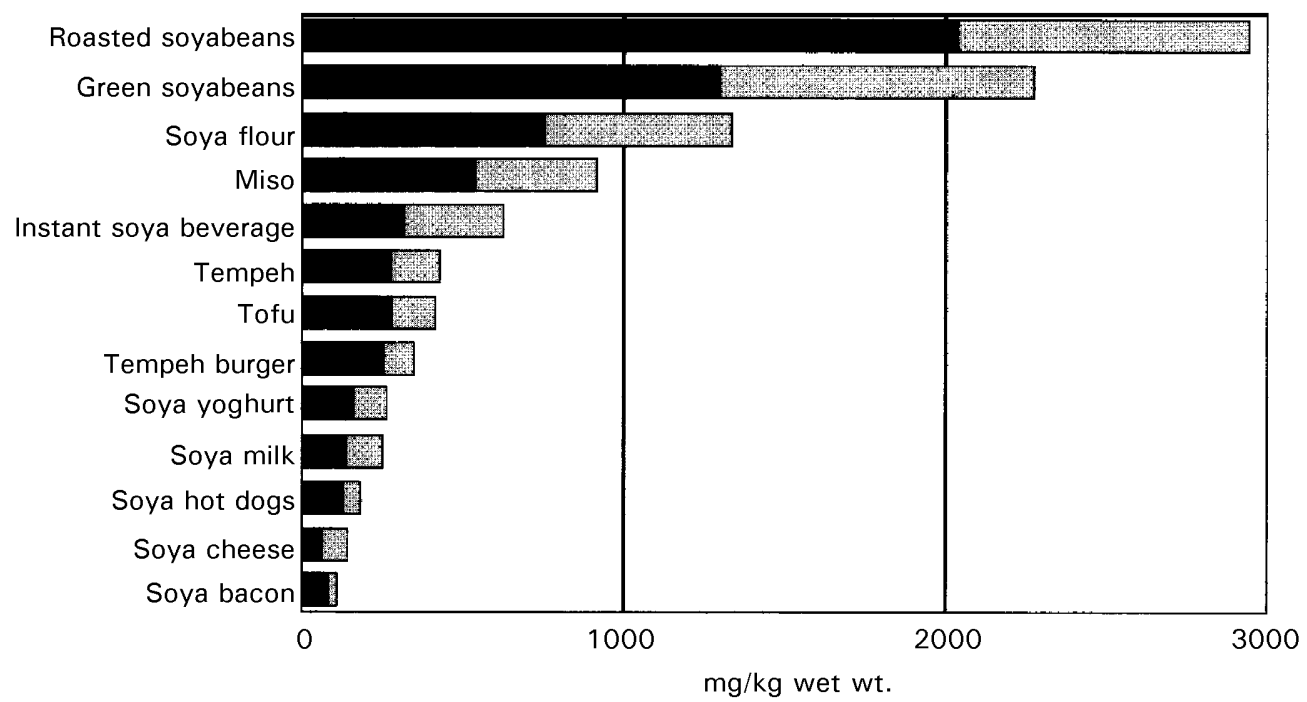

Fig. 1. Isoflavone contents of various soyabean products. Isoflavone contents of soyabean foods are expressed as $\mathrm{mg} / \mathrm{kg}$ food (wet wt.) ( $\mathbf{0}$ ), Genistein; (国), daidzein. Note that the genistein: daidzein ratio is approximately $3: 2$ to $2: 1$ for a variety of soyabean foods. Taken from Coward et al. (1993) and Wang \& Murphy (1994).

daidzein. Clearly the concentrations of isoflavones in the derivative or second generation soyabean foods are lower than those of the soyabeans themselves or soyabean products made directly from soyabeans. The concentration of isoflavones decreases in the derivative soyabean foods because of dilution with other constituents and losses during processing. For instance, many of the second generation soyabean products are made from soyabean concentrate that has been extracted with ethanol to make the food more palatable. The aqueous-ethanol extraction method can remove $>90 \%$ of the isoflavones, although less rigorous extraction methods are generally used. The isoflavones appear to be resistant, however, to degradation by commonly used food preparation methods, e.g. baking, frying, etc.

While coumestrol is an important phyto-oestrogen in animal diets, the coumestans are present in only a few foods commonly consumed by humans. Table 1 lists those foods that contain potentially significant amounts of coumestrol, the primary coumestan consumed by humans.

Food processors and manufacturers of dietary supplements have obviously become aware of the interest in the potential benefits of phyto-oestrogen consumption on prevention of cardiovascular disease, cancer, and osteoporosis. The available data consist of a mixture of epidemiological studies examining the relationship between consumption of natural foods

Table 1. Coumestrol content of foods*

\begin{tabular}{lc}
\hline Food item & Coumestrol $(\mathrm{mg} / \mathrm{kg})$ \\
\hline Clover (genus Trifolium) sprouts & 280.6 \\
Round split peas (Pisum sativum), dry & 81.1 \\
Kala chana (Cicer arietinum) & 61.3 \\
Lucerne (Medicago sativa) sprouts & 46.8 \\
Pinto bean (Phaselous vulgaris) seeds, dry & 36.1 \\
Large lima bean (Phaselous limensis) seeds, dry, raw & 14.8
\end{tabular}

\footnotetext{
${ }^{*}$ From Franke et al. (1994).
} 
containing phyto-oestrogens and disease prevalence, a relatively few studies of human subjects in which purified or enriched phyto-oestrogen preparations are taken prospectively, and a burgeoning number of animal and in vitro studies. The increased availability of isoflavoneenriched supplements and new food items containing significant amounts of natural or supplemented phyto-oestrogens will probably lead to an increase in consumption of these molecules by the population. Because of the connection of the phyto-oestrogens with reduced risk of osteoporosis and cancer, particularly breast cancer, women are more likely to choose to increase their consumption of these dietary molecules.

\section{Structures of major phyto-oestrogens}

The phyto-oestrogens can interact with oestrogen receptors, and the similarity of their structures to the $17 \beta$-oestradiol molecule is believed to explain this mimicry. These molecules share several features in common with the oestradiol structure (Fig. 2), including a pair of hydroxyl groups separated at a similar distance; one hydroxyl group is a substituent of an aromatic A ring while the second hydroxyl lies at the opposite end of the molecule (Miksicek, 1993).

The oestrogen-like structures of the phyto-oestrogens help explain the ability of these molecules to occupy the oestrogen receptor; however, the interaction is not equivalent since both the occupancy time and affinity for the receptor are significantly reduced for phytooestrogens (Miksicek, 1994). In addition, small differences in the structures of individual isoflavones dramatically alter their oestrogenicity. Daidzein and genistein share identical structures except for an additional hydroxyl group on the A ring of genistein; however, genistein may have up to 5-6-fold greater oestrogenic activity in some assays (Markiewicz et al. 1993).

The isoflavones are present in foods in multiple chemical forms. The aglycone form is considered the active form of the molecules, but they may be only a small percentage of the total isoflavones. The glucoside (glycone) form and acetyl- and malonylglucosides are the<smiles>O=c1c(-c2ccc(O)cc2)coc2cc(O)ccc12</smiles><smiles>O=c1c(-c2ccc(O)cc2)coc2cc(O)cc(O)c12</smiles>

Daidzein<smiles>Oc1ccc2c(c1)CCC1C2CCC2C(O)CCC21</smiles><smiles>COc1cc2c(=O)c(-c3ccc(O)cc3)coc2cc1O</smiles>

Glycitein<smiles></smiles>

Coumestrol

Fig. 2. Chemical structures of the major phyto-oestrogen molecules in comparison with $17 \beta$ oestradiol. The phyto-oestrogens are drawn with the B ring up to emphasize the similarity to the oestradiol molecule. 
major forms found in soyabean and soyabean products. Some of the fermented soyabean products, such as fermented bean curd, have aglycones as the major isoflavone form (Wang \& Murphy, 1994). The conversion of isoflavones from glucosides to aglycones is accomplished in the gut, and metabolism also includes generation of the primary isoflavone molecules, genistein and daidzein, from precursors with lower oestrogenicity (Fig. 3). Biochanin A and formononetin, found in clover sprouts and a few other legumes, are readily converted by gut flora to genistein and daidzein respectively. Genistein can be further metabolized in the gut to compounds such as 4-ethylphenol, and daidzein to compounds such as equol, dihydrodaidzein, and $O$-desmethylangolensin. Although genistein and daidzein have been used for most experimental studies of isoflavone action, data suggest that the daidzein metabolite equol may also exert significant biological effects (Hodgson et al. 1996). Equol, which has a greater antioxidant effect than other phyto-oestrogens, is often the isoflavone found in highest concentration in the blood and urine.

\section{General cellular actions of phyto-oestrogens}

Cells containing large numbers of oestrogen receptors (OR), specifically breast and uterine cells, were studied initially in an attempt to understand better the actions of specific phytooestrogens. The original observations that female sheep became reproductively inefficient following the ingestion of fresh subterranean clover (Trifolium subterraneum) led Australian scientists to conclude that excesses of coumestan-rich clover exerted adverse effects on uterine and possibly ovarian function (Bennetts, 1946).

Other investigators have demonstrated that the amounts of phyto-oestrogens required to produce classical oestrogenic effects on reproductive tissues similar to that of a physiological dose of $17 \beta$-oestradiol are approximately 1000 -fold or greater in experimental animal models. In isolated cell lines of bone cells, however, the amounts of phyto-oestrogens required for equivalent effects of $17 \beta$-oestradiol may be about the same (JJB Anderson, T Ohue and SC Garner, unpublished results). This significant difference in the effects of oral dosages, approximately $10^{-3}$ or greater, could result both from inefficient absorption of the bioactive

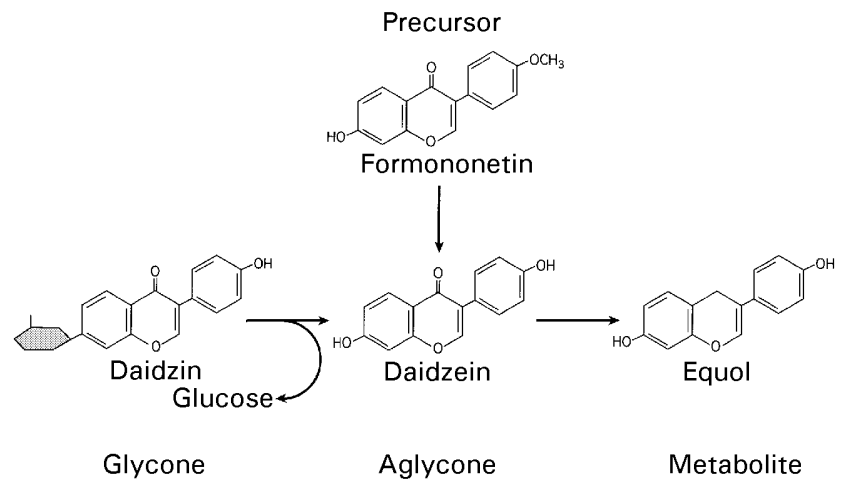

Fig. 3. Phyto-oestrogen metabolism. Daidzein, the aglycone form of this phyto-oestrogen, may be derived from intestinal metabolism of the aglycone or other precursor molecules. Further metabolism of the phyto-oestrogen may also yield metabolites with oestrogenic activity, e.g. equol. 


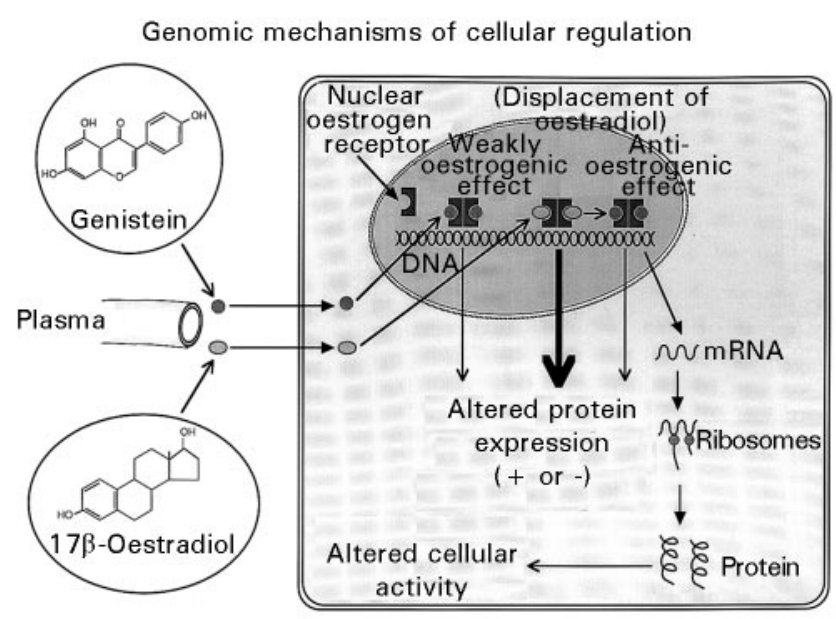

Fig. 4. Classical genomic mechanism through which oestrogens and phyto-oestrogens act. Binding of the oestrogen or phyto-oestrogen molecule, e.g. genistein, to the nuclear oestrogen receptor initiates dimerization of the receptor and interaction with oestrogen response elements on DNA. Activation or inhibition of gene transcription results in altered protein expression. Binding of a phyto-oestrogen may be interpreted to result in either a weakly oestrogenic effect or an antioestrogenic effect based on displacement of oestrogen molecules.

molecules (Xu et al. 1995) and differential effects of these compounds in various tissues (Anthony et al. 1996; Anderson et al. 1998).

Once the fat-soluble phyto-oestrogens are delivered from the gut to the tissues via chylomicrons, they have two potential fates at the cellular level: (1) they are taken up by passive diffusion across the cell membrane and act via the classical oestrogen mechanism as weak agonists; or (2) they interact with membrane proteins (receptors) and exert an effect that is expressed through second messengers in the cytoplasm (see below).

The classical action of phyto-oestrogens, using genistein as the model molecule, consists of several steps: combination with OR in the cytosol, movement of the genistein-OR complex into the nucleus for activation of the oestrogen response element after dimerization with one of several possible molecules, stimulation of DNA-directed mRNA synthesis, and the production of new protein molecules specific to the tissue cell-type (Fig. 4).

Oestrogen regulation of genes has also been shown to involve an alternative pathway in which the occupied oestrogen receptor combines with c-Fos and c-Jun oncoproteins and regulates gene transcription via AP-1 sites (Gaub et al. 1990; Weisz \& Rosales, 1990; Umayahara et al. 1994).

Since the discovery of a second type of OR, OR- $\beta$ (Kuiper et al. 1996), tissues have been found to vary in their expression of OR- $\alpha$ and OR- $\beta$. Some cells, especially breast and uterus, have been reported to be rich in OR- $\alpha$, whereas others, such as bone, are rich in OR- $\beta$ (Kuiper et al. 1997; Onoe et al. 1997), although this description may be an oversimplification. A differential distribution of OR, which have varying affinities for oestrogen agonists, may be part of the explanation for the dissimilar responses of various tissues to any single oestrogen agonist and the altered response of a single tissue to different oestrogenic molecules. For example, a selective oestrogen receptor modulator (SORM), like raloxifene, has little effect on repro- 
Table 2. Relative binding affinities and relative potencies of major phyto-oestrogens compared with $17 \beta$ oestradiol

\begin{tabular}{lcc}
\hline Molecule & Relative binding affinity* & Relative potency ${ }^{*}$ \\
\hline Oestradiol & 1.0 & 1.0 \\
Coumestrol & 0.13 & 0.0020 \\
Genistein & 0.0125 & 0.0008 \\
Daidzein & 0.0010 & 0.00013 \\
Biochanin A & 0.00005 & $<0.000006$ \\
\hline
\end{tabular}

*Adapted from Miksicek (1994). The relative binding affinities are calculated as the inverse of the concentration excess, relative to $17 \beta$-oestradiol, required to give $50 \%$ inhibition of specific binding of $17 \beta-\left[{ }^{3} \mathrm{H}\right]$ oestradiol to oestrogen receptors expressed in COS-7 cells, e.g. a 20000 -fold excess of biochanin A is required for $50 \%$ inhibition.

$\uparrow$ Adapted from Markiewicz et al. (1993). The relative potencies are based on the concentrations of phyto-oestrogens that exert one-half of their maximum effects $\left(E C_{50}\right)$ on alkaline phosphatase $(E C$ 3.1.3.1) in endometrial adenocarcinoma cells (Ishikawa-Var I) with the potency of oestradiol set at 1.0.

ductive tissues, but has bone-conserving properties. (These diverse properties of molecules with oestrogenic activity has led to the generation of the term SORM.) Phyto-oestrogens, especially genistein, are thought to act like SORM, although additional experimental work is needed to clarify the actions of specific phyto-oestrogens on OR.

Phyto-oestrogens have generally been reported to have lower binding affinity for oestrogen receptors (Miksicek, 1994) and lower potency in producing oestrogenic effects (Markiewicz et al. 1993) compared with $17 \beta$-oestradiol. As shown in Table 2 , the relative binding affinities with the oestrogen receptor and relative potencies in inducing alkaline phosphatase (EC 3.1.3.1) activity in endometrial adenocarcinoma cells in culture have a similar rank order for major phyto-oestrogens. The values for relative binding affinities of phyto-oestrogens, however, tend to be several-fold higher compared with oestradiol than the corresponding potency in the endometrial cell line. Other cell types, including cells of the cardiovascular system, bone cells, and cancer cells of many different tissues may have different responses to the various phytooestrogens.

Steroid molecules, which include oestrogen and the other sex hormones, adrenal steroids, and 1,25-dihydroxyvitamin $\mathrm{D}$, have recently been suggested to have effects on membranebound receptors that do not involve activation of the genomic machinery of the cell (Nemere, 1995, 1996; Machelon et al. 1996; Benten et al. 1997; Le Mellay et al. 1997). Several researchers have reported that addition of $17 \beta$-oestradiol to osteoblasts and other cells in culture stimulates increases in intracellular $\mathrm{Ca}^{2+}$ within seconds to minutes (Picotto et al. 1996; Le Mellay et al. 1997; Benten et al. 1998). The changes in this potential intracellular second messenger are much too rapid to involve changes in protein synthesis via the nuclear steroid receptors. Although it has not been demonstrated experimentally, phyto-oestrogens probably are also recognized by the putative cell-surface oestrogen receptors. In addition, other effects of phyto-oestrogens that involve activation of several possible second messengers, including kinase enzymes, may in turn stimulate or inhibit downstream pathways of metabolism and protein products. Many of these potential mechanisms of action of phyto-oestrogens are illustrated in Fig. 5.

The duration of the effects of phyto-oestrogens mediated via an interaction with membrane protein(s) is considered to be short-lived and with limited efficacy, unless the stimulating molecules are continuously available in solutions bathing cells. In studies of isolated cells in culture in which the media are frequently exchanged, the continuous dosing of cells with a phyto-oestrogen is easy to visualize. In animal models or humans, it is less certain that suffi- 


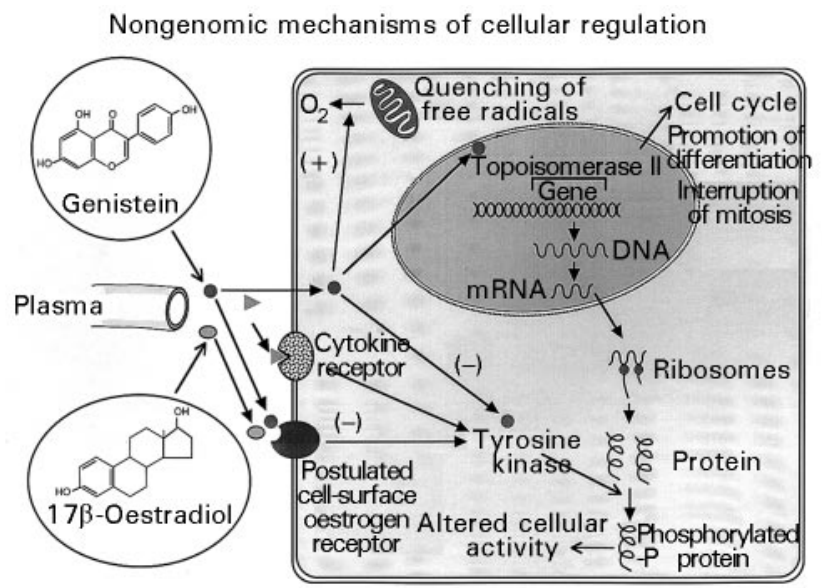

Fig. 5. Non-genomic mechanisms through which oestrogens and phyto-oestrogens may act. Oestrogens and phyto-oestrogens may bind to the postulated cell-surface oestrogen receptor to alter cellular activity. Phyto-oestrogens, particularly genistein, may have other effects via inhibition of tyrosine kinase (EC 2.7.1.112) activity, quenching of free radicals, or inhibition of topoisomerase II (EC 5.99.1.3), which alters the cell cycle.

ciently high blood concentrations can be maintained over long periods, i.e. weeks to months, to have a significant impact on cells. Studies of isolated immortal osteoblast-like cells (ROS and ROS.SMER) treated with genistein suggest that the membrane mechanism of action can modestly, but significantly, upregulate the cellular production of alkaline phosphatase approximately 20-30\% above basal unstimulated production (JJB Anderson, T Ohue and SC Garner, unpublished results). At the same time, genistein appears to have little or no effect on the classical OR mechanism in these cells, as shown by lack of any inhibitory effect of the pure oestrogen antagonist, ICI 182,780 (during the first 4-6 d in culture) (JJB Anderson, T Ohue and SC Garner, unpublished results).

In summary, both true oestrogens and phyto-oestrogens exert their effects on target cells containing viable OR by two mechanisms, the classical OR-induced series of steps, and the new membrane-protein interaction. Elevated concentrations of oestrogens can be maintained throughout fairly long periods, such as during parts of the menstrual cycle and during pregnancy. Similarly, phyto-oestrogen concentrations in blood may also be maintained at fairly high levels by ingestion of soyabean products at several meals each day, as is the case of many Japanese who consume 30-50 g soyabean-containing foods/d (Adlercreutz et al. 1993; Messina, 1995). Therefore, exposure of cells to oestrogens and/or phyto-oestrogens during these periods would be presumed to activate both the OR and the membrane proteins. Tissues with greater numbers of OR- $\alpha$, e.g. breast and uterus, would probably be more affected by true oestrogens than by phyto-oestrogens, but tissues with higher expression of OR- $\beta$ (e.g. bone) might be more responsive to phyto-oestrogens.

\section{Effects of phyto-oestrogens on cardiovascular disease and its risk factors}

Phyto-oestrogens have recently been shown to have several effects on cardiovascular tissues. These effects may reduce the risk of cardiovascular diseases. 


\section{Effects of soyabean protein on plasma lipids and atherosclerosis}

The replacement of animal protein in the diet with soyabean protein has long been associated with hypocholesterolaemic and atherosclerosis-preventive effects (Meeker \& Kesten, 1941). Anderson et al. (1995b) have reported on a meta-analysis assessing the effects of dietary soyabean protein on plasma lipid concentrations in which soyabean protein supplementation resulted in a reduction of approximately $13 \%$ in plasma LDL-cholesterol concentrations, $11 \%$ reduction in plasma triacylglycerol, and $2 \%$ increase in HDL-cholesterol. If one stratifies the results by baseline total plasma cholesterol concentrations, the effects of dietary soyabean protein supplementation on total cholesterol and LDL-cholesterol concentrations are most robust among those with the highest plasma cholesterol at baseline. Recently, Nagata et al. (1998) reported a significant trend for lower plasma cholesterol concentrations with increasing soyabean intake after adjustment for potential confounders for both men $(n 1242, P$ for trend $=0.0001)$ and women $(n 3596, P$ for trend $=0.0001)$ in a prospective cohort study in Takayama City, Japan. These studies suggest that soyabean proteins may be useful for improving plasma lipoprotein concentrations and for prevention of cardiovascular disease.

\section{Cardiovascular protective components of soyabean}

While the cardioprotective effects of soyabean protein are well accepted, the component(s) responsible for these effects is currently the subject of much research. During the 1970s and early 1980s the amino acid composition was investigated for its effect on plasma lipid and lipoprotein metabolism and its role in atherosclerosis inhibition.

Huff et al. (1977) reported one such study that seems to reflect the overall findings of these studies. Groups of rabbits ( $n$ 6-10 per group) were fed on diets that contained either casein or soyabean protein or mixtures of amino acids that duplicated the amino acid composition of each protein. For casein or its amino acid mixture the plasma cholesterol concentrations of the two groups were found to be essentially the same. However, for soyabean protein the amino acid mixture was not as hypocholesterolaemic as the intact protein, providing evidence that there were components of the intact soyabean other than the amino acids that independently lowered plasma cholesterol concentrations or interacted with the protein moiety to affect lipoprotein metabolism favourably.

More recently, evidence has accumulated that the component of soyabean protein responsible for a large part of its cardioprotective effects is an alcohol-extractable molecule(s) (Sugano \& Koba, 1993; Anthony et al. 1996, 1997; Balmir et al. 1996; Kirk et al. 1998; Tovar-Palacio et al. 1998). The alcohol-extractable components that may have the potential to lower plasma lipid concentrations are the saponins, phytosterols and isoflavones. The bulk of evidence regarding saponins is that they exert no hypocholesterolaemic effect in the presence of soyabean protein (Potter et al. 1993). In addition, most soyabean protein isolates have low amounts of phytosterols because of delipidation and extensive processing required to obtain the isolates (Anderson \& Wolf, 1995). The isoflavones (non-steroidal phyto-oestrogens), which are largely removed from soyabean protein when it is washed with alcohol, have been reported to alter plasma lipid concentrations and are currently being actively investigated for their role in cardiovascular disease protection.

\section{Effects of soyabean phyto-oestrogens on plasma lipids and lipoproteins}

Several studies provide evidence that the phyto-oestrogens in soyabean modulate plasma lipid and lipoprotein concentrations, but the data are not entirely consistent. For the purpose of this review, only published reports for which the study design allows an assessment of the iso- 
flavones (phyto-oestrogens) as the likely mediating factor on cardiovascular endpoints will be included.

In one report (Balmir et al. 1996), rats ( $n 6$ per group) were fed for $28 \mathrm{~d}$ on diets containing soyabean protein extracted with ethanol to remove the phyto-oestrogens (soya $(-)$ ), unextracted soyabean protein with the phyto-oestrogens intact (soya $(+))$, casein (casein), or casein with $0.36 \mathrm{mg}$ alcohol-extract of soyabean flour added per g protein (casein $(+)$. The alcohol-extract was treated with acetone to precipitate sugars, saponins and proteins; thus it was principally a phyto-oestrogen-containing extract. All of the diets contained moderate amounts of fat, predominantly saturated fats, and were cholesterol-free. The groups fed on the casein $(+)$, soya(-), and soya $(+)$ diets had significantly lower LDL-cholesterol concentrations than the casein group, but the former three groups were not significantly different from each other. The HDLcholesterol concentrations tended to be higher in the two groups fed on the diets containing isoflavones relative to the isoflavone-devoid groups. In a second study (Balmir et al. 1996) with hamsters ( $n 10$ per group), the casein, casein $(+)$, and soya $(+)$ diets were the same as described earlier. Two additional groups were included in this study, a group fed on the unextracted soyabean protein with $0.36 \mathrm{mg}$ isoflavone-containing extract added per g protein $(\operatorname{soya}(++))$ and a group fed on casein with $0.72 \mathrm{mg}$ extract added per g protein (casein $(++))$. The effects of all these diets on LDL- + VLDL-cholesterol concentrations were examined. The soya $(+)$, soya $(++)$, and casein $(+)$ groups had significantly lower LDL- + VLDL-cholesterol concentrations than the casein group. The LDL- + VLDL-cholesterol concentration of the casein $(++)$ group was also lower than for the casein group but not significantly so. Therefore, while both soyabean protein and the isoflavone-containing extract lowered LDL- + VLDL-cholesterol concentrations, no additional benefit was seen for the groups receiving the higher dose of isoflavone extract $($ casein $(++)$ and soya $(++))$ in these two species.

Kirk et al. (1998) have reported on a study in which they fed diets containing unextracted soyabean protein isolate (soya $(+)$ ) or alcohol-washed soyabean protein (soya $(-)$ ) to C57BL/6 (wild-type) mice and LDL receptor-deficient (LDLr-null) mice. The wild-type (soya(-), $n$ 16; soya $(+), n 20$ ) were treated for 10 weeks and the LDLr-null groups (soya $(-), n=9$; soya $(+)$, $n 8$ ) for 6 weeks. Among the wild-type mice the soya $(+)$ group had significantly lower total and LDL- + VLDL- cholesterol concentrations than the soya(-) group. HDL-cholesterol concentrations were not different between groups. Among the LDLr-null mice, no significant difference was observed in total plasma cholesterol between diet groups. The authors interpreted these differences in response of the two strains of mice to suggest that soyabean isoflavones might lower plasma cholesterol concentrations by increasing LDL receptor activity, thus the lack of effect of the isoflavone-containing soyabean protein to lower plasma cholesterol in the LDL receptor-deficient mice.

Studies in non-human primates support the hypothesis that soyabean phyto-oestrogens play a primary role in modulating plasma lipid and lipoprotein concentrations (Anthony et al. 1996, 1997, 1998). In a cross-over study in young rhesus monkeys (Macaca mulatta) ( $n$ 25), the animals were fed on diets containing soyabean protein isolate from which the isoflavones had been extracted with ethanol (soya $(-))$ or with the isoflavones intact (soya $(+))$ (Anthony et al. 1996). Plasma LDL- + VLDL-cholesterol concentrations were significantly lower with the soya $(+)$ diet in both males and females. Additionally, in the females the soya $(+)$ diet consumption resulted in significantly improved HDL-cholesterol concentrations relative to when they were fed on the soya $(-)$ diet.

In another study with non-human primates (Anthony et al. 1997, 1998), young cynomolgus monkeys (Macaca fasicularis) (males, $n 77$; females, $n$ 70) were fed on diets containing either 
casein and lactalbumin (casein), alcohol-extracted soyabean protein isolate (soya $(-))$, or unextracted soyabean-protein isolate $(\operatorname{soya}(+))$ as the source of protein. The diets were identical for other components. During the 14-month treatment period, plasma lipid concentrations were measured. There was a robust LDL- + VLDL-cholesterol-lowering effect and HDL-cholesterol-raising effect $(P=0.0001)$ of the phyto-oestrogen-intact soyabean protein relative to the phyto-oestrogen-extracted soyabean observed in both males and females $(P=0.0001$ for the combined data for each measure). A large part of the benefit of soyabean protein is lost when it is alcohol-washed. It seems likely that the loss of the beneficial effects of soyabean protein isolate on plasma lipids and lipoproteins is due to the extraction of the phytooestrogens.

Additional support for the hypothesis that the isoflavones are an important modulator of plasma lipoprotein concentrations comes from a recently completed study by Crouse et al. (1998). In this randomized clinical trial, mildly hypercholesterolaemic men ( $n 94)$ and women $(n 62)$ were treated with protein supplements ( $25 \mathrm{~g}$ protein in each) that contained casein, alcohol-extracted soyabean protein isolate ( $3 \mathrm{mg}$ isoflavones), or soyabean protein isolate that contained $27 \mathrm{mg}$, $37 \mathrm{mg}$, or $62 \mathrm{mg}$ isoflavones/d. The treatment phase lasted 9 weeks. The $62 \mathrm{mg}$ isoflavone group $($ soya $(++))$ had significantly lower LDL-cholesterol concentrations than the casein group $(P<0.05)$ while the alcohol-extracted soyabean protein (soya $(-))$ had no effect. The authors also reported a dose-response relationship with progressively lower total and LDL-cholesterol concentrations with increasing isoflavone dose.

Baum et al. (1998) recently completed a study comparing the effects of soyabean protein isolate containing two different concentrations of isoflavones with a control protein (casein and non-fat dry milk) in postmenopausal women (total $n$ 66). All subjects received $40 \mathrm{~g}$ protein/d and the isoflavone doses for the two soyabean protein groups were $56 \mathrm{mg} / \mathrm{d}($ soya $(+))$ or $90 \mathrm{mg} / \mathrm{d}($ soya $(++))$. The soya $(++)$ protein was similar in isoflavone content to that used in the study described earlier by Crouse et al. (1998). The difference in isoflavone dose with this product, $90 \mathrm{mg} / \mathrm{d}$ for Baum et al. (1998) and $62 \mathrm{mg} / \mathrm{d}$ for Crouse et al. (1998), results from the difference in the amount of protein given each day, $40 \mathrm{~g} v .25 \mathrm{~g}$, respectively. Both doses of isoflavones resulted in significantly lower LDL- + VLDL-cholesterol and higher HDL-cholesterol concentrations relative to the control group. No evidence was found of a dose-response effect on these endpoints.

The beneficial effects of soyabean phyto-oestrogens on plasma lipids and lipoproteins appear convincing. The LDL cholesterol-lowering effects of soyabean isoflavones have been shown in various animal models, including mice, rats, hamsters, cynomolgus and rhesus monkeys, and human subjects. The LDL-cholesterol-lowering effects have been seen when isoflavone-containing extracts have been added to casein-based diets, a significant attenuation of LDL-cholesterol lowering has been demonstrated when the isoflavones are removed from soyabean protein by alcohol extraction, and a dose-response effect on LDLcholesterol lowering has been shown with increasing isoflavone concentration in the dose range of 3-62 mg isoflavones/d. Studies with transgenic mice suggest that the benefits of isoflavones on cholesterol lowering may be mediated through upregulation of LDL-receptor activity.

\section{Effects of soyabean phyto-oestrogens on vascular reactivity}

Vascular reactivity in response to acetylcholine is a measure of vascular function and can be evaluated by repeated quantitative angiography. Changes in the diameter of a coronary artery 
are measured after intracoronary infusion of acetylcholine, which induces endothelium-mediated vasodilation in normal arteries and constriction in atherosclerotic arteries of oestrogendeficient subjects. Honoré et al. (1997) compared the effects of unextracted soyabean protein isolate (soya $(+), n 5)$ and phyto-oestrogen-extracted soyabean protein (soya $(-), n 6)$ in young pre- and peripubertal rhesus monkeys and reported that the soya $(+)$ diet significantly improved vascular reactivity. They also repeated this test in the soya(-) group and administered genistein (the principal phyto-oestrogen in the soyabean protein isolate) intravenously 20 min before angiography and found that genistein had similar oestrogen-like effects on vascular reactivity (vasodilatation) relative to soya $(-)$ treatment. These data further support the hypothesis that the phyto-oestrogens, and genistein in particular, are the components in soyabean responsible for cardioprotection.

\section{Effects of soyabean phyto-oestrogens on atherosclerosis}

A much smaller body of experimental evidence supports a protective effect of soyabean phytooestrogens on atherosclerosis. One piece of evidence is from a study of young cynomolgus monkeys in which the animals were fed on diets containing either casein and lact-albumin, alcohol-extracted soyabean-protein isolate (soya $(-))$, or unextracted soyabean protein isolate $(\operatorname{soya}(+))$ as the source of protein (Anthony et al. 1997). Coronary artery atherosclerosis extent was quantified on a subset of monkeys from each treatment group (soya $(-), n$ 18; soya $(+)$, $n$ 15). Average lesion size in the soya $(+)$ group was approximately $70 \%$ smaller $(P=0.05)$ than in the soya(-) group (MS Anthony, TB Clarkson and TB Bullock, unpublished results). These data would suggest that the alcohol-extractable material, probably the phyto-oestrogens, inhibits atherogenesis.

In another study in surgically postmenopausal cynomolgus monkeys, the effects of soyabean with its phyto-oestrogens were compared with those of conjugated equine oestrogens (Premarin $^{\circledR}$ (Wyeth-Ayerst Laboratories, Philadelphia, PA, USA), the most commonly used oestrogen-replacement therapy in the USA) on atherosclerosis in the iliac artery (Anthony \& Clarkson, 1998). Animals were randomized into one of three groups: (1) a group fed on a diet containing isoflavone-extracted soyabean protein (soya $(-), n 56),(2)$ a group fed on soyabean protein with the phyto-oestrogens intact (soya $(+), n 59)$, or (3) a group fed on the isoflavone-

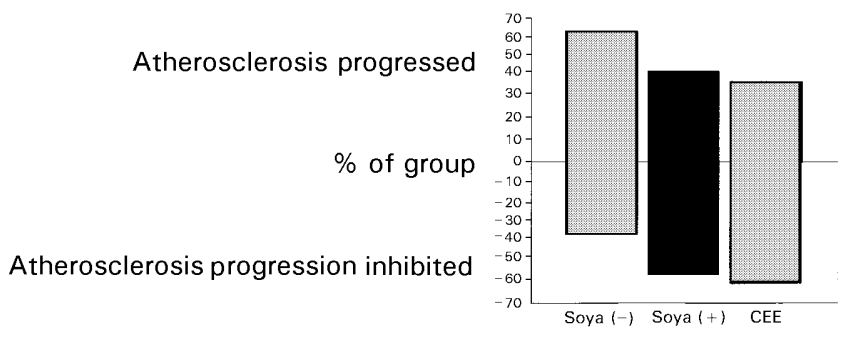

Fig. 6. Effects of phyto-oestrogen-extracted soyabean protein (soya(-), $n 56$ ), phyto-oestrogenintact soyabean protein (soya $(+), n 59$ ) or conjugated equine oestrogens (CEE, Premarin ${ }^{\mathbb{R}}$ (Wyeth-Ayerst Laboratories, Philadelphia, PA, USA), $n$ 63) on atherosclerosis progression in the common iliac artery of surgically postmenopausal cynomolgus monkeys (Macaca fasicularis). Data are expressed as the percentage of each group in which atherosclerosis progressed or was inhibited. Soya (+) v. soya(-), $P=0.03$; CEE $v$. soya $(-), P=0.007$; soya(+) $v$. CEE, $P=0.62$. Adapted from Anthony \& Clarkson (1998). 
extracted soyabean protein with Premarin ${ }^{\circledR}$ ( $n$ 63) added to approximate the usual dose for women. Atherosclerosis progression in the common iliac artery was evaluated after 3 years of treatment. Fig. 6 shows the percentage of each group that demonstrated atherosclerosis progression or inhibition of atherosclerosis progression. These data suggest that both soyabean phyto-oestrogens and conjugated equine oestrogen inhibit atherosclerotic plaque progression relative to the phyto-oestrogen-extracted soyabean protein-treated control group, and the effects of the two treatments are similar.

Kirk et al. (1998) recently evalulated the effects of diets containing either intact or phytooestrogen-extracted soyabean on atherosclerosis in two strains of mice, LDL receptor-deficient (LDLr-null) and wild-type (C57BL/6) mice. Among the wild-type mice, lesion area was significantly smaller in those fed on intact or unextracted soyabean protein compared with phytooestrogen-extracted soyabean protein, but no difference in the extent of atherosclerosis was seen in the LDL receptor-deficient mice. The effects on atherosclerosis are similar to those for plasma and LDL-cholesterol (described earlier), suggesting that isoflavones modulate plasma cholesterol concentrations by increasing LDL-receptor activity and thereby inhibiting atherogenesis.

While the data are just now accumulating, soyabean protein containing phyto-oestrogens appears to protect against atherosclerosis progression. The magnitude of the effect appears to be comparable to that of traditional postmenopausal oestrogen therapy (Premarin ${ }^{\circledR}$ ). The LDL receptor appears to play a role in modulating the effects of the isoflavones. These data on the benefits of soyabean protein containing isoflavones, which reduce the extent of atherosclerosis, are encouraging for the prospect of reducing the risk of CHD.

\section{Lack of an effect of purified isoflavones on plasma lipid concentrations}

Two recent reports have evaluated the effects of purified phyto-oestrogen pills on cardiovascular disease risk factors. The first was a randomized, placebo-controlled cross-over trial, in which menopausal and perimenopausal women $(n$ 21) were treated with either purified isoflavone pills containing about $80 \mathrm{mg}$ isoflavones ( $45 \mathrm{mg}$ genistein, $34 \mathrm{mg}$ daidzein, $3 \mathrm{mg}$ glycitin) or a placebo for 5-week periods (Nestel et al. 1997). These investigators found improved systemic arterial compliance with isoflavone pill treatment, but no effect on plasma lipids. The second half of the cross-over was extended to a 10 -week period to see if additional treatment time was required for plasma lipid effects, but there continued to be no effect of purified isoflavones on the plasma lipid concentrations. In a second randomized, placebo-controlled, double-blind trial, forty-six men and thirteen postmenopausal women were treated with purified phyto-oestrogen pills containing $55 \mathrm{mg}$ isoflavones (16 mg biochanin $\mathrm{A}, 30 \mathrm{mg}$ genistein, $8 \mathrm{mg}$ formononetin, $1 \mathrm{mg}$ daidzein) isolated from subterranean clover, for 8 weeks (Hodgson et al. 1998). No effect of the purified phyto-oestrogen pills was found on plasma lipid and lipoprotein concentrations.

In considering these studies together with the two previously cited human studies (Baum et al. 1998; Crouse et al. 1998), one of the differences is that where no cholesterol-lowering effect of the phyto-oestrogens was shown, the subjects were not selected to be hypercholesterolaemic. Thus Crouse et al. (1998) reported no significant effect on total cholesterol or LDL-cholesterol with the soyabean protein supplements in the half of the subjects with LDL-cholesterol concentrations below the median at baseline. Other possible explanations for a lack of effect of purified isoflavones include: (1) the phyto-oestrogens are not the active agent: it is some other unidentified component that is removed with alcohol extraction and is present in soyabean in 
concentrations parallel to the phyto-oestrogens; (2) the phyto-oestrogens are inactivated when they are isolated and purified and (3) an enabling factor in soyabean protein allows the phytooestrogens to have the beneficial effects on plasma lipids and lipoproteins.

\section{Discussion}

Considerable evidence exists that soyabean with its phyto-oestrogens has a beneficial effect on cardiovascular disease, preventing the progression of atherosclerosis by interaction with multiple biological processes. A large part of this benefit appears to be mediated by effects on plasma lipid and lipoprotein concentrations. Soyabean phyto-oestrogens, and genistein in particular, also impact beneficially on vascular reactivity. Another potential benefit of soyabean phyto-oestrogens, which has been shown in vitro, is prevention of lipoprotein oxidation (Hodgson

et al. 1996; Ruiz-Larrea et al. 1997). The resulting decrease in oxidized LDL particles, which are considered more atherogenic (Witztum \& Steinberg, 1991), may decrease the risk of atherosclerosis. The phyto-oestrogens in soyabean protein may also have some direct effects on the artery wall and the cells involved in promotion and progression of atherosclerosis. Genistein has been shown, in vitro, to inhibit the migration and proliferation of smooth muscle cells (Fujio et al. 1993; Shimokado et al. 1994, 1995), to inhibit platelet activation (Kuruvilla et al. 1993; Murphy et al. 1993) and aggregation (Asahi et al. 1992; McNicol, 1993), and to reduce platelet serotonin uptake (Helmeste \& Tang, 1995). Each of these effects of genistein may delay the development of atherogenesis.

It remains to be shown that an intervention incorporating soyabean with its phytooestrogens into a western-type diet can favorably impact cardiovascular disease morbidity and mortality (e.g. stroke, myocardial infarction). Questions remain regarding dose and form of the phyto-oestrogens to maximize the benefits and minimize any potential risks. Incorporation of soyabean with its phyto-oestrogens into a western diet, however, may prove to be an important means for prevention of cardiovascular disease and may have additional benefits for other chronic diseases.

\section{Areas for further investigation}

Several gaps in our knowledge of phyto-oestrogens remains to be investigated if these molecules are to be considered as a preventive therapy for cardiovascular disease:

(1) The appropriate dose of phyto-oestrogens required for cardiovascular benefit is uncertain.

(2) The relative potency of each of the two principal phyto-oestrogens in soyabean, genistein and daidzein, of the much less abundant glycitin, and of the metabolites (e.g. equol, $O$-desmethylangolensin, dihydrodaidzein, 4-ethylphenol) needs to be determined and compared with parent compounds. Whether some optimum ratio of the phyto-oestrogens exists should also be determined.

(3) The question remains why purified isoflavone preparations appear to have no effect on plasma lipid and lipoprotein concentrations, although step-wise reductions in LDLcholesterol levels occur with increasing doses of isoflavones administered in soyabean protein.

(4) For soyabean phyto-oestrogens to be considered for primary prevention of cardiovascular disease, their safety in other organ systems must be established. 


\section{Effects of phyto-oestrogens on skeletal tissues}

The published data supporting a beneficial effect of phyto-oestrogens on bone mass are limited, but reports have been rather consistent in support of positive bone effects of isoflavones and other phyto-oestrogens in human subjects, most experimental animal models, and bone explants or bone cells in vitro. An increase in bone mass could result from either increased bone formation by osteoblasts or decreased bone resorption by osteoclasts, and would thus help to prevent the development of osteoporosis. Although the cellular mechanism of action of phytooestrogens on bone may involve either osteoblasts or osteoclasts, OR are present in relatively low numbers in osteoblasts while mammalian osteoclasts are not believed to express these receptors. Thus, a genomic effect of phyto-oestrogens, consistent with their ability to interact with the ligand-binding portion of the OR in vitro, may underlie a direct effect of these molecules on osteoblasts, while other responses of osteoblasts or osteoclasts may result from either indirect mechanisms or non-genomic actions (see later).

\section{Investigations of phyto-oestrogen effects on bone in human subjects}

In human subjects, phyto-oestrogen molecules may benefit bone mass by direct effects via bone cells; however, the consumption of soyabeans or soyabean protein, as an extract or hydrolysate, apparently has a conservatory effect on $\mathrm{Ca}$. In contrast to the animal protein lactalbumin (a milk protein), isolated soyabean protein, which contains isoflavones, exerts a modest decrease in urinary Ca excretion during both the postprandial and $24 \mathrm{~h}$ periods (Anderson et al. 1987). In addition, the consumption of soyabean protein stimulates glucagon during the postprandial period at a much greater rate than lactalbumin. Based on the results of this study, however, it may have been the isoflavones that exerted the favorable effect on $\mathrm{Ca}$ retention following soyabean consumption. Whatever the acute mechanism of soyabean protein (containing isoflavones) on $\mathrm{Ca}$ conservation is, it is highly significant, and it may help to offset lower $\mathrm{Ca}$ intakes among vegetarians and counter other potentially adverse dietary factors in the diets of vegans (Anderson \& Miller, 1998).

Post-menopausal women in general may benefit from dietary supplementation with isoflavone-enriched soyabean products to maintain bone mass. A report (Potter et al. 1998) of soyabean supplementation of sixty-six postmenopausal women compared bone measurements at baseline and 6 months after feeding a soyabean-protein supplement enriched in genistein and daidzein (doses of approximately 56 and $90 \mathrm{mg}$ of isoflavones/d), compared with treatment with a casein/non-fat dry milk supplement (no isoflavones). The higher dose resulted in significant improvements $(P<0.05)$ in both bone mineral density and content of lumbar vertebrae relative to the control group, with no significant benefit in subjects receiving the lower dose. These findings, which illustrate the positive responses of vertebral bone mineral density of the postmenopausal women in the study, suggest that a threshold dose exists for any benefit of isoflavones on bone mineral density. Longer prospective studies examining the effects of phyto-oestrogens on bone parameters of postmenopausal women are needed to clarify effective doses and whether other skeletal sites will also benefit from isoflavones over a longer time frame of treatment.

Some evidence is also available that consumption of soyabean proteins can reduce urinary markers of bone resportion. Pansini et al. (1997) reported that non-osteoporotic, post- 
menopausal women who consumed $60 \mathrm{~g}$ isolated soyabean proteins daily for 3 months had significant reductions in both deoxypyridinoline and N-telopeptide excretion.

In addition to the limited data on effectiveness of naturally-occurring isoflavones in preventing bone loss in postmenopausal women, the bone-conserving effects of chronic treatment with ipriflavone, a synthetic isoflavone, in women with low bone mass have been reported. Gennari et al. (1997) studied 453 postmenopausal women in a double-blind, placebo-controlled, 2-year study with random assignment of women to either ipriflavone $(200 \mathrm{mg}$ three times per day) or placebo; all women received $1 \mathrm{~g} \mathrm{Ca} / \mathrm{d}$ orally. The final outcome showed a significant $(P<0.05)$ difference between the placebo groups, which lost $1.6 \%$ at one study centre and $3.5 \%$ of bone mass at the second centre, and the ipriflavone group, which maintained bone mass (approximately $0 \%$ loss).

Data on the effectiveness of phyto-oestrogens in promoting bone accretion and bone retention in young adult women are also needed in addition to longer trials with these dietary molecules in older women. An increase in peak bone mineral density of young women may possibly delay or prevent development of osteoporosis in later life. Crucial data are required from longer human trials with isoflavones establishing the long-term benefits of these nonsteroidal molecules.

\section{Animal model experiments of phyto-oestrogen effects on bone}

Some of the limited number of published reports on the skeletal effects of phyto-oestrogens on animals are highlighted here.

Rodent studies. The most commonly used animal model for examining the effect of molecules with the potential for anti-osteoporotic actions has been the ovariectomized (OVX) rat. Three different studies have been reported in which OVX rats have been treated with either soyabean with its naturally-occurring isoflavones, a genistein-rich soyabean isoflavone preparation, or purified genistein. Feeding an isoflavone-containing soyabean protein-based diet to OVX rats resulted in retention of significantly more bone than feeding a casein-based diet (Arjmandi et al. 1996). Similarly, OVX lactating rats treated with a genistein-rich soyabean isoflavone preparation for $14 \mathrm{~d}$ retained significantly more bone mass than vehicle-treated controls (Anderson et al. 1995a; JJB Anderson, WW Ambrose and SC Garner, unpublished results). Purified genistein also promoted a similar improvement in femur bone mass of OVX rats (Blair et al. 1996). The common factor among these three studies was the presence of isoflavones, including genistein. The studies by Anderson et al. (1995a; JJB Anderson, WW Ambrose and SC Garner, unpublished results) found that soyabean isoflavones had an apparent biphasic effect on bone retention. A similar biphasic response in which lower doses had significant effects on bone while higher doses produced less benefit has been reported for bonederived cells in culture as discussed later. Further studies of the effects of phyto-oestrogen molecules over a broad dose range are needed to determine whether a potentially narrow range exists for beneficial effects of phyto-oestrogens as suggested by these findings of a biphasic relationship.

The research reported above involved the isoflavones found in soyabean products. These molecules have been studied most frequently because soyabean is the most common source of phyto-oestrogens in the human diet. However, the human diet also includes many legumes, such as lima beans (Phaseolus limensis), pinto beans (Phaseolus vulgaris), and sprouts of clover (genus Trifolium) or lucerne seeds (Medicago sativa) (Franke et al. 1994), that contain 
significant amounts of another phyto-oestrogen, coumestrol (Table 1). Dodge et al. (1996) found significant effects of coumestrol but not of genistein, on prevention of bone loss in rats after ovariectomy. Coumestrol administered orally appeared to be equally effective compared with ethinyl oestradiol in preventing bone loss, but doses at least 100-times higher were required. In another study, injection of coumestrol to OVX rats twice per week has been reported to cause a similar significant improvement in femur bone mass to that shown with oestradiol (Draper et al. 1997). Interestingly, the same report contained results of an experiment in which dietary supplementation with an isoflavone-containing extract from subterranean clover did not significantly improve the bone mass of OVX rats. A similar finding was obtained by JJB Anderson, WW Ambrose and SC Garner (unpublished results) for young, growing OVX rats, which had modest, but not significant, gains in femur bone mass after 4 weeks of treatment with a genistein-rich soyabean isoflavone extract.

Significant bone retentive effects of the synthetic isoflavone, ipriflavone, have also been reported. Cecchini et al. (1997) found that either $400 \mathrm{mg} / \mathrm{kg}$ body weight of ipriflavone mixed in the food of OVX rats or subcutaneous injection of $27.2 \mathrm{~g} / \mathrm{kg}$ of $17 \beta$-oestradiol per day could decrease bone resorption to values of sham-operated animals. Although ipriflavone produced similar bone effects to that of oestradiol, no significant uterotrophic effect was observed.

Non-human primate studies. Although clearly valuable, relatively few primate studies of the effects of phyto-oestrogens on bone mass have been published and positive effects of isoflavones on retention of bone after ovariectomy in non-human primates have been difficult to demonstrate. One prospective study in which primates were treated with a single dose of isoflavones (28 mg per animal) for 2 years has been published (Jayo et al. 1996). No positive effects of the isoflavones on bone measurements were reported. The investigators suggested that the lack of significant improvement in bone mass in this experiment could have resulted from the use of a single dose of isoflavones, which may have been too small to produce a positive effect on bone mass or that the Ca level in the diet (equivalent to a human intake of about $800 \mathrm{mg} / \mathrm{d}$ ) was too low. Additional research has been reported by the same group (Register et al. 1997) in which they fed OVX macaques (genus Macaca) for 6 months on either casein/lactalbumin or soyabean protein diets with and without oestrogen. Serum Ca was significantly increased in the soyabean protein-fed groups compared with the casein/ lactalbumin groups, which is consistent with the finding of Anderson et al. (1987) that soyabean protein could conserve $\mathrm{Ca}$ in humans.

An additional study in OVX cynomolgus monkeys examined the rate of bone formation in cortical bone (Lees \& Ginn, 1998). All animals were OVX, and bone was collected 7 months after feeding on either casein or soyabean-based diets with and without treatment with oestradiol. While oestradiol significantly reduced bone formation rates at periosteal, osteonal, and endocortical surfaces, the only statistically significant effect of the soyabean diet was an increase in bone formation at the endocortical surface. The authors conclude that phyto-oestrogens in the dietary soyabean isolate are effective in improving cardiovascular risk factors but not bone under the same conditions.

The difficulty of demonstrating positive effects of isoflavones on retention of bone after ovariectomy may be consistent with the concept that the dose of isoflavones necessary to demonstrate gains in bone tissue is relatively high, about $90 \mathrm{mg} / \mathrm{d}$. This requirement is congruent with studies using rodent models. Also the animal experimental results suggest that a threshold dose of isoflavones needs to be consumed for a lengthy period of time, i.e. months to years, before any measurable effect on bone can be observed. Doses higher than the threshold appear to be no more beneficial than the minimal effective dose; very high doses are less effective, and if too high, they may even be toxic. 
In vitro bone cell studies of phyto-oestrogens

The use of bone tissue or osteoblast-like and osteoclast-like cells in culture have provided important information about the effects of phyto-oestrogen molecules on bone activity.

Bone tissue in organ culture. A single published study has examined the effects of phytooestrogens on bone tissues in organ culture. Tsutsumi (1995) reported that coumestrol inhibited bone resoption and stimulated bone mineralization in 9-d-old chick embryonic femur explants. In addition, the increased bone resorption resulting from treatment with parathyroid hormone, the hormonal form of vitamin $\mathrm{D}$, or prostaglandin $\mathrm{E}_{2}$ could be inhibited by coumestrol or $17 \beta$ oestradiol. The author reported that the optimal effects were obtained with approximately $10^{-5} \mathrm{M}$-coumestrol, which is about 100-1000-fold higher than the optimal concentration of oestradiol (Miksicek, 1994).

Osteoblast-like cells. Studies of osteoblast-like cells in culture have shown that they respond to phyto-oestrogens. Different cell lines with osteoblast-like properties have been examined in vitro to confirm and extend the research on effects of phyto-oestrogens on bone in vivo. An important finding from at least two laboratories has been the biphasic response of osteoblast-like cells to a wide range of concentrations of phyto-oestrogens (Benvenuti et al. 1991; Anderson \& Garner, 1997).

Benvenuti et al. (1991) tested the effects of ipriflavone, a synthetic flavone molecule with a structure closely related to the isoflavones, on bone cells in vitro. They found the alkaline phosphatase (EC 3.1.3.1) activity of UMR-106 osteoblast-like cells responded to increasing doses of ipriflavone with a biphasic response (Fig. 7). The peak activity of alkaline phosphatase of approximately three times that of the baseline for control cells was found at $10^{-10} \mathrm{M}$ ipriflavone.

The effects of genistein and $17 \beta$-oestradiol on alkaline phosphatase activity have also been examined in the ROS-SMER-14 osteoblast-like cell line (Fig. 8) (T Ohue, SC Garner and JJB Anderson, unpublished results). It was found that both the ROS-SMER-14 and its parent ROS $17 / 2.8$ cell lines responded with modest increases in alkaline phosphatase activity. Although the ROS.SMER-14 cells express approximately eight times as many oestrogen receptors as the ROS $17 / 2.8$ cells (Migliaccio et al. 1992), the responses of alkaline phosphatase to addition of

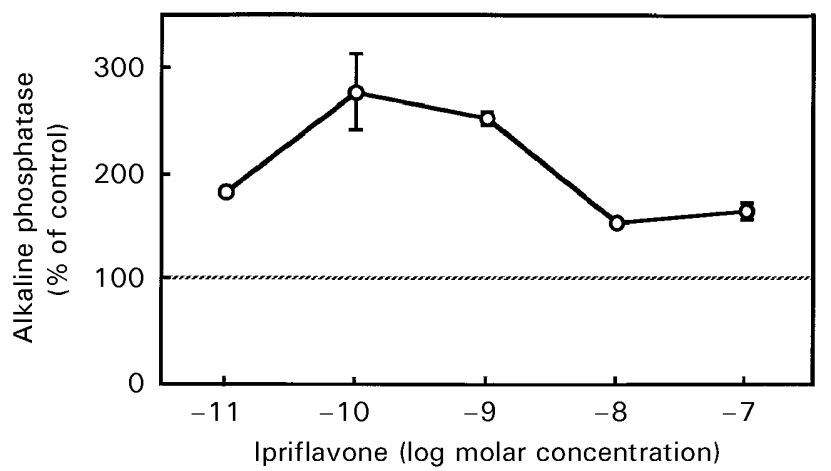

Fig. 7. Ipriflavone, a synthetic isoflavone, exerts a biphasic effect on alkaline phosphatase (EC 3.1.3.1) activity in UMR-106 osteoblast-like cell line (adapted from Benvenuti et al. 1991). Vertical lines represent SE. 
genistein $\left(10^{-10}-10^{-8} \mathrm{M}\right)$ were similar in both cell lines, suggesting that other mechanisms of action of phyto-oestrogens may be operating in these cells. At higher $\left(10^{-6}-10^{-4} \mathrm{M}\right)$ concentrations of genistein and $17 \beta$-oestradiol both ROS.SMER-14 and ROS 17/2.8 cells assumed a more rounded appearance with reduced contacts with other cells and the culture plate. The presence of DNA ladders after gel electrophoresis suggests that this an apoptotic rather than a toxic effect (JJB Anderson, T Ohue and SC Garner, unpublished results). The differential effects of genistein and $17 \beta$-oestradiol on alkaline phosphatase and cell morphology suggest that some effects of these molecules may be through similar mechanisms of action, while some bone-related effects may involve non-oestrogenic actions of genistein or other phyto-oestrogens. A closely related phyto-oestrogen, daidzein, did not produce a biphasic response in the same osteoblast-like cells (T Ohue, SC Garner and JJB Anderson, unpublished results).

Studies of osteoblast-like cells in culture demonstrate that these cells respond to phytooestrogens and related molecules. Comparison of the effects of isoflavones and chemically similar molecules, however, demonstrates that various cell lines may respond differently to phyto-oestrogens. Further, the responses of bone cells in vivo may be different from those observed in vitro, and it is likely that our knowledge of the mechanisms of action of phytooestrogens on osteoblasts will continue to unfold in the next few years.

Osteoclast-like cells. Inhibition of osteoclastic cell activity in vivo by oestrogens, and possibly phyto-oestrogens, is believed to be mediated via osteoblasts since mammalian osteoclasts are generally considered not to express oestrogen receptors. Despite this postulated relationship in vivo, however, direct inhibitory effects of phyto-oestrogens have been demonstrated on avian osteoclasts in vitro by Blair et al. (1996). They found that genistein, but not the structurally similar molecule daidzein, could exert this effect. Both Blair et al. (1996) and Williams et al. (1998) proposed that isoflavones inhibited activities of osteoclast-like cells by interfering with specific enzymatic systems, such as the tyrosine kinase (EC 2.7.1.112) activity of epidermal growth factor receptor protein, i.e. a non-genomic mechanism. Tobe et al. (1997) assayed parathyroid hormone-stimulated bone resorption by mixed cultures of mouse bone cells on dentine slices in vitro. The number of resorption pits was inhibited by calcitonin and significantly stimulated by daidzein but not genistein or ipriflavone. Further research will be required to resolve these reports of divergent actions of phyto-oestrogens on osteoclasts in vitro.

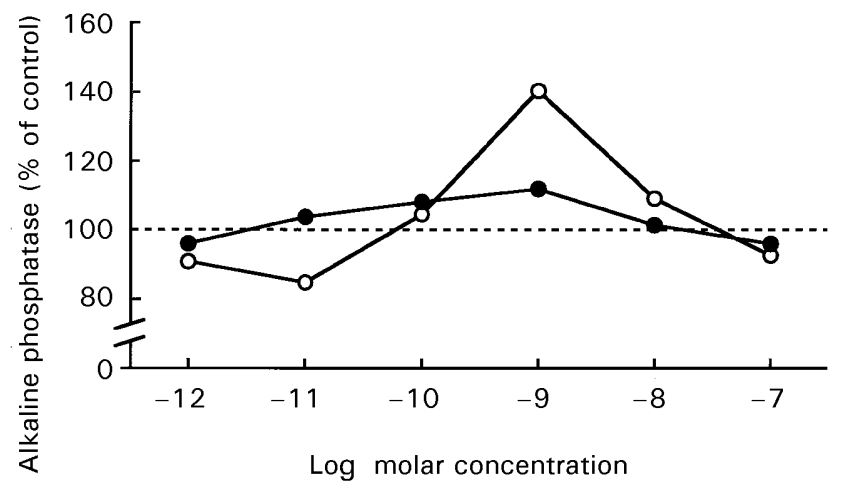

Fig. 8. Alkaline phosphatase (EC 3.1.3.1) activity is significantly increased by both genistein $(O)$ and $17 \alpha$-oestradiol (O) in ROS.SMER-14 osteoblastic cells (T Ohue, SC Garner and JJB Anderson, unpublished results). 
Summary. Taken together these studies suggest that isoflavones, and possibly other phytooestrogens, may operate by both oestrogen-receptor-mediated pathways and by pathways that involve so-called non-genomic mechanisms that could involve both the putative cell-surface oestrogen receptor and enzymatic pathways such as tyrosine kinase (see later). Isolated bone cells and cell lines will continue to provide valuable models for future studies of the effects of the many non-steroidal oestrogen-like molecules on the health benefits of soyabean-derived isoflavones and other phyto-oestrogens.

\section{Mechanisms of action of phyto-oestrogens on osteoblasts and osteoclasts}

Phyto-oestrogens, like oestrogens, are thought to interact at the cellular level by two major mechanisms: genomic and non-genomic.

Interactions of phyto-oestrogens with the oestrogen receptor. The oestrogen receptor is believed to act primarily through altering the production of specific proteins within the cell by binding to regulatory sites on DNA molecules (oestrogen response elements (ORE)) and increasing or decreasing expression of specific genes. Depending on the affinity of the phytooestrogen molecule for the OR, binding of a phyto-oestrogen to the receptor may result in partial activation of the receptor (weak agonistic effect) or displacement of an oestrogen molecule, which may reduce receptor activation (antagonistic or anti-oestrogenic effect).

Phyto-oestrogens combine with the OR but at lower affinities than $17 \beta$-oestradiol. The affinities of selected phyto-oestrogens for the oestrogen receptor in comparison to $17 \beta$-oestradiol are listed in Table 2. Miksicek (1993) has demonstrated that diverse naturally occurring and synthetic molecules can activate human nuclear oestrogen receptors in an in vitro reporter assay. Although the non-steroidal oestrogens are less potent than $17 \beta$-oestradiol, they do generate the same maximal response when the dose tested is high enough. These findings suggest that the cumulative effect of the many molecules of plant origin with weak agonism may be a significant factor in human health, including the maintenance of bone mass.

Nearly all cell types are believed to be affected by oestrogens in some way because OR are present in almost all mammalian cells that have nuclei, with the possible exception of osteoclasts. The response of different cells may depend in large part, therefore, on the number of OR, which may be approximately 100-1000 times higher in reproductive tissues than in most other cells of the body, including bone cells. Migliaccio et al. (1992) reported that oestrogens could activate oestrogen receptors present in both the wild type ROS 17/2.8 cells and in the ROS.SMER-14 cells stably transfected with mouse uterine OR.

The genomic effects of oestrogens are believed to be mediated via an intracellular oestrogen receptor that activates gene transcription by interacting with ORE. A second intracellular OR molecule has recently been discovered (Kuiper et al. 1996). The classical OR is now designated OR- $\alpha$ and the more recently discovered, structurally similar, protein has been named OR- $\beta$. Initial reports suggest that the phyto-oestrogens, genistein and coumestrol, have a significantly higher affinity for OR- $\beta$ than for OR- $\alpha$ (Kuiper et al. 1997).

Both OR- $\alpha$ and OR- $\beta$ are expressed in bone cells (Arts et al. 1997; Onoe et al. 1997). Recently published reports indicate that the expression of OR- $\alpha$ and/or OR- $\beta$ may vary during differentiation of osteoblasts in vitro. The pattern of expression, however, may be dependent on the particular cells being studied. While Onoe et al. (1997) found that primary cultures of rat osteoblasts expressed OR- $\beta$ at a relatively constant level during $28 \mathrm{~d}$ in culture, the expression of OR- $\alpha$ increased by $7-8$-fold in parallel with osteoblastic differentiation. Bodine et al. (1998) 
also examined OR- $\alpha$ expression in primary rat osteoblasts. They found a 70-fold increase in OR- $\alpha$ mRNA levels by days $22-25$ of culture. In contrast, Arts et al. (1997) found that a human osteoblastic cell line (SV-HFO) had approximately 10-fold higher levels of OR- $\beta$ mRNA expression in mineralizing (day 21) cells $\nu$. proliferating (day 6) cells, but OR- $\alpha$ mRNA increased only approximately 2 -fold.

OR- $\alpha$ and OR- $\beta$ can form heterodimers (Cowley et al. 1997; Pettersson et al. 1997) and, thus, the responsiveness of cells may differ depending on the relative expression of the two receptor subtypes. Paech et al. (1997) examined the differential ligand activation of OR- $\alpha$ and OR- $\beta$ with an ORE reporter construct and with an AP-1 reporter construct. Although oestradiol and a panel of ligands, including tamoxifen and raloxifene, had almost the same activation profile with the ORE reporter construct with both OR, the responses of the AP-1 reporter construct were distinctly different. Oestrogen activated the AP-1 reporter construct in the presence of OR- $\alpha$ but not OR- $\beta$, while tamoxifen was a potent activator of both OR- $\alpha$ and OR$\beta$. The next few years promise to be an exciting period of research into the role of these two oestrogen receptor subtypes in explaining some of the differential effects of oestrogenic compounds, including phyto-oestrogens, on bone cells compared with reproductive tissues.

Non-genomic mechanisms. Phyto-oestrogens may interact with other cellular proteins in addition to the classical oestrogen receptor. The existence of membrane-bound receptor for oestrogenic molecules has been proposed (Watson et al. 1995). In addition, genistein has been demonstrated to inhibit tyrosine kinase (Akiyama et al. 1987) and topoisomerase II (EC 5.99.1.3) (Okura et al. 1988). An important function of the phyto-oestrogens in plant cells is as antioxidants, and it is likely that they could perform the same function in animal cells. Proposed actions of phyto-oestrogens through non-genomic mechanisms are supported by the direct action of phyto-oestrogens on osteoclasts (Williams et al. 1998), which appear to lack oestrogen receptors. The major effect of phyto-oestrogens on osteoclasts may still be mediated via osteoblasts however, since secretion of cytokines by osteoblastic cells is believed to be the major mechanism for regulation of osteoclastic activity in response to calcaemic hormones and oestrogen.

The potential mechanisms by which phyto-oestrogens may affect cellular activities are illustrated in Figs. 4 and 5. The mechanisms of action are divided into the genomic and nongenomic effects of phyto-oestrogens. The genomic effect involves OR and activation of the ORE, whereas non-genomic actions involve membrane receptors and cytosolic enzymes.

\section{Discussion}

These more recent investigations of the oestrogenic activities of the isoflavones, either as partial oestrogen agonists or anti-oestrogens (inhibitors of natural oestrogen activity), are clearly relevant to bone health and disease. Soyabean isoflavones, mainly genistein and daidzein, have now been shown by at least four different laboratories to conserve bone in OVXrodent models. They probably have similar bone conservatory effects in higher mammalian species. The phyto-oestrogen coumestrol, which is not commonly consumed by humans, may be more potent than the soyabean isoflavones in preserving bone mass. Clearly the application of phyto-oestrogens for the prevention and treatment of osteoporosis is approaching.

These published reports support the concept that a threshold dose of isoflavones needs to be consumed for a sufficiently long period of time, i.e. months to years depending on the species, before any measurable effects on bone mass and density can be observed. A further 
complexity appears to be that consumption of higher doses does not convey further benefit of isoflavones, with higher doses possibly being less effective. Although it is possible that extremely high doses may even have adverse effects, such events are not likely from food sources alone. However, the increasing availability of isoflavone-enriched food supplements and purified phyto-oestrogens in capsule form should be viewed with caution because of our current lack of knowledge of the potential toxicity of these molecules. Greater information from human studies currently in progress, however, is needed before the efficacy of these preparations in human subjects is known. The use of soyabeans and their products make this approach, as opposed to drug formulations that preserve bone, more attractive to many postmenopausal women.

The consumption of practically any soyabean product means that isoflavones will also be consumed from these foods in amounts that depend on the degree of processing (see Fig. 1). The doses of phyto-oestrogens that are effective in in vitro studies are approximately $10^{-8} \mathrm{M}$, but these concentrations are difficult to translate to either animal models or human studies. Nevertheless, the only positive effects of phyto-oestrogens on bone observed so far in postmenopausal women have been small and limited to the lumbar vertebrae. Although data have not yet been published from several human studies in progress, additional evidence for skeletal benefits of soyabean isoflavones is anticipated in the next few years. It may also be necessary to accumulate data from studies lasting decades to assess the effects of lifelong intakes of soyabean products at levels similar to those of high-consuming Asian populations.

\section{Soyabean intake and cancer risk}

Within the past few years soyabean foods and certain soyabean components have attracted considerable research attention for their potential role in cancer prevention and treatment. A critical early development in this field was the conclusions of a workshop by the National Cancer Institute, USA, in 1990 which led to the Institute allocating significant funds toward investigating the anticancer potential of soyabean components (Messina \& Barnes, 1991). Understandably, initial interest in the anticancer effects of soyabean focused primarily on breast cancer. Early enthusiasm for this relationship was based largely on three primary observations: (1) the low breast cancer mortality rates in Asian, soyabean food-consuming countries; (2) animal work showing that soyabean inhibits chemically induced mammary carcinogenesis (Barnes et al. 1990); and (3) the potential anti-oestrogenic effects of soyabean isoflavones.

A comprehensive review by Messina et al. (1994) noted that the evidence supporting the potential anticancer effects of soyabean, although far from conclusive, was by no means limited to breast cancer. Published data suggest that soyabean may reduce the risk of a variety of cancers and, in particular, cancer of the prostate. Consequently, this section on cancer focuses primarily on breast and prostate cancer, and in particular the potential anticarcinogenic effects of the soyabean isoflavones. Although several different putative anticarcinogens have been identified in soyabeans, including phenolic acids (Ramakrishna et al. 1989), phytosterols (Rao \& Janezic, 1992), protease inhibitors (Bowman Birk Inhibitor and Kunitz inhibitor; Kennedy \& Manzone, 1995), inositol hexaphosphate (Graf \& Eaton, 1993), saponins (Koratkar \& Rao, 1997), and melanoidins (miso) (Kamei et al. 1997), the evidence most strongly supports a role for the isoflavones in the hypothesized anticancer effects of soyabean. 


\section{Isoflavones as anticarcinogens}

As noted previously, three primary aglycone isoflavones are present in soyabeans: genistein, daidzein and glycitein. Glycitein is present in relatively small amounts and little is known about its biological activity, although it has been shown to be a weak oestrogen (Sonn et al. 1997). The isoflavone daidzein has exhibited anticancer effects both in vitro (Hirano et al. 1989; Higashi \& Ogawara, 1994) and in animal models (Jing et al. 1993); however, the greatest focus has been on genistein. Recently, the Chemopreventive Branch of the Division of Cancer Prevention and Control, National Cancer Institute, National Institute of Health in the United States published its clinical development plan for genistein (Chemopreventive Branch and Agent Development Committee, 1996).

Literally hundreds of in vitro studies show that genistein can inhibit the growth of a wide range of both hormone-dependent and hormone-independent cancer cells with an $\mathrm{IC}_{50}$ of between approximately $5 \times 10^{-6}$ and $10^{-4} \mathrm{M}$ (approximately $2-25 \mu \mathrm{g} / \mathrm{ml}$ ). Genistein has been shown to be effective in inhibiting growth of breast cancer cell types and many others (Table 3 ). In addition, genistein has been shown to inhibit the metastatic activity in vitro of both breast (Scholar \& Toewa, 1994) and prostate cancer cells (Santibáñez, 1997), independent of effects on cell growth.

In a variety of cell lines, including cells derived from human gastric cancer (Yanagihara, 1993), oestrogen-receptor positive and negative human breast carcinoma cell lines (Shao et al. 1998), leukaemic cells (Spinozzi, 1994), melanoma cells (Rauth et al. 1997), and colon cancer cells (Kuo, 1996), genistein arrested cell cycle progression at $\mathrm{G}_{2}-\mathrm{M}$. These studies also showed that the addition of genistein to cancer cells induces differentiation and apoptosis.

The precise mechanism(s) by which genistein inhibits the growth of cancer cells has not been identified, but several have been proposed. Although the antioxidant properties of geni-stein (Wei et al. 1993) may contribute to the anticancer effects observed in vitro, it is more likely that these effects result from the ability of this isoflavone to modulate multiple processes associated with neoplastic transformation (Table 4). In addition to these effects, Peterson et al. (1996) reported that genistein increased the in vitro concentration of transforming growth factor beta.

\section{Soyabean intake and breast cancer}

As noted earlier, in addition to the low breast cancer mortality rates in Asian countries, much of the enthusiasm for the anticancer effects of soyabean foods was because weak oestrogens,

Table 3. Selected cancer cell types inhibited by genistein in vitro

\begin{tabular}{ll}
\hline Cell type & \multicolumn{1}{c}{ Reference } \\
\hline Breast cancer & Peterson \& Barnes, 1991, 1996 \\
Prostate cancer & Pagliacci et al. 1994 \\
& Peterson \& Barnes, 1993 \\
Melanoma & Naik et al. 1994 \\
Leukaemia & Kyle et al. 1997 \\
Gastric cancer & Rauth et al. 1997 \\
Colon cancer & Makishima et al. 1993 \\
\hline
\end{tabular}


Table 4. Multiple processes associated with neoplastic transformation that may be modulated by genistein

\begin{tabular}{ll}
\hline Protein target of genistein & \multicolumn{1}{c}{ Reference } \\
\hline Tyrosine-specific protein kinase & Akiyama et al. 1987 \\
Mitogen-activated protein (MAP) kinases & Thorburn \& Thorburn, 1994 \\
DNA topoisomerase II (EC 5.99.1.3) & Constantinou et al. 1990 \\
Epidermal growth factor-induced phosphatidylinositol turnover & Imoto et al. 1988 \\
S6 kinase activation & Linassier et al. 1990 \\
\hline
\end{tabular}

including isoflavones, have been posulated to function as anti-oestrogens in vivo (Geynet $e t$ al. 1972; Martin et al. 1978). On a molar basis, relative to physiological oestrogens, isoflavones are quite weak, possessing between $1 \times 10^{-4}$ and $1 \times 10^{-3}$ the activity of $17 \beta$-oestradiol (Folman \& Pope, 1966; Mayr et al. 1992; Markiewicz et al. 1993). Although data are conflicting on this point, limited support exists for the notion that isoflavones are anti-oestrogenic. In fact, more than 30 years ago Folman \& Pope (1966) demonstrated in female mice that subcutaneous injection of genistein inhibited oestrone-stimulated increases in uterine weight. More recently, genistein (Wang et al. 1996) and equol (Sathyamoorthy \& Wang, 1997) were shown to inhibit oestradiol-stimulated pS2 mRNA expression in MCF-7 cells. In addition, genistein, daidzein and equol were found to down-regulate oestrogen receptor mRNA expression.

The prevailing hypothesis has been that isoflavones exert anti-oestrogenic effects when placed in a high oestrogen environment, such as exists in premenopausal women, and oestrogenic effects in a low oestrogen environment, such as in postmenopausal women. This hypothesis has some support; for example, Mäkelä et al. (1995) found that soyabean consumption led to an increase in uterine weight in OVX mice not given the synthetic oestrogen diethylstilbestrol, but to a decrease in uterine weight in mice given diethylstilbestrol (Fig. 9). Also, Foth \& Cline (1998) found that soyabean-feeding partially antagonized the stimulatory effect of oestrogen on endometrial and breast cancer tissue in OVX macaques, although soyabean had slight stimulatory effects on proliferation in the breast tissue of animals not given oestrogen.

Another potentially important observation related to the anti-oestrogenic hypothesis was reported by Cassidy et al. (1994, 1995), who found that premenopausal women consuming $60 \mathrm{~g}$ textured soyabean product (containing $45 \mathrm{mg}$ isoflavones) experienced a $2.5 \mathrm{~d}$ increase in the length of their follicular phase, whereas no change was noted in women fed on a similar amount of soyabean from which the isoflavones had been chemically removed (Cassidy et al. 1995). Particularly noteworthy is the finding that serum follicle stimulating hormone and luteinizing hormone levels decreased significantly in response to the consumption of soyabean isoflavones.

Findings that soyabean increases follicular phase length may be quite relevant to the soyabean-breast cancer hypothesis because some data indicate that longer cycles, which are typical of Asian women, are associated with a reduced risk of breast cancer (Olsson et al. 1983; Yuan et al. 1988). However, Wu \& Pike (1995) have pointed out that in the studies by Cassidy et al. (1994, 1995), serum oestrogen levels were not decreased, whereas serum oestrogen levels are typically lower in Asian compared with western women. In contrast to Cassidy et al. (1994, 1995) however, Lu et al. (1996a) observed an increase in menstrual cycle length in response to soyabean consumption and a decrease in serum oestrogen levels. The difference between the studies is perhaps a result of the much higher isoflavone intake in the latter study. To complicate this issue further, however, two recent studies failed to find an effect of soyabean on menstrual cycle length or oestrogen levels (Duncan et al. 1998; Haggins et al. 1998). 


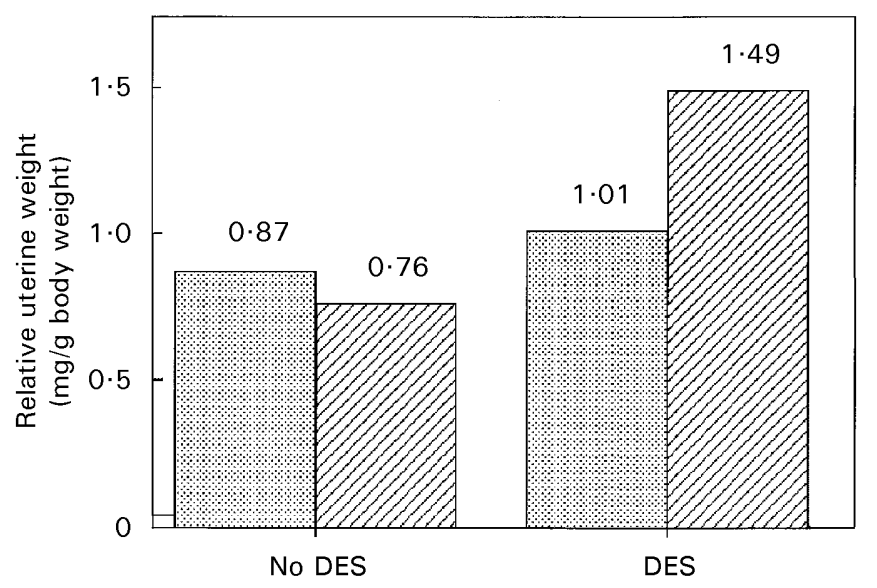

Fig. 9. Relative uterine weight of mice fed on a soyabean-containing or soyabean-free diet with or without diethylstilbestrol (DES). Outbred Han-NMRI mice were fed on either an Ewos R3 diet that contained roasted soyabean meal $(70 \mathrm{~g} / \mathrm{kg}$ diet) (国) or the equivalent soyabean-free nonpurified diet (Ewos R403) in which casein was substituted for soyabean meal (Did). Diets were with $(6 \mu \mathrm{g} / \mathrm{kg})$ or without DES. The uterine weight of animals fed on soyabean without DES $(n 32)$ was significantly higher than the uterine weight $(n 33)$ of animals not fed on soyabean. The uterine weight of the animals $(n 18)$ fed on soyabean and DES was significantly lower than the uterine weight of animals ( $n$ 22) fed on DES but not on soyabean. Statistical significance (two-way ANOVA) of effect of dietary soyabean, $P<0.05$; effect of DES, $P<0.001$; interaction between dietary soyabean and DES, $P<0.001$. Adapted from Mäkelä et al. (1995).

Although some evidence suggests that isoflavones are anti-oestrogenic under some conditions, other research supports a primarily oestrogenic effect of isoflavones (Mäkelä et al. 1994; Dees et al. 1997; Santell et al. 1997; Zava \& Duwe, 1997). Importantly, genistein has a biphasic effect on oestrogen receptor-positive breast cancer cell growth in vitro; at micromolar concentrations growth inhibition occurs, whereas modest growth stimulation occurs at lower concentrations. The lower concentrations, however, may more accurately reflect those likely to occur in vivo (Zava \& Duwe, 1997). Consistent with these findings is work by Santell et al. (1997), who found that genistein increased uterine weight in OVX Sprague-Dawley rats without inhibiting the increase in uterine weight caused by oestradiol administration.

Finally, two studies involving premenopausal women concluded that soyabean exerts oestrogenic effects on breast tissue. In one, nipple aspirates of secreted breast fluids, which have been shown to be an indicator of breast cancer risk by Wrensch et al. (1991), increased in response to soyabean consumption over a 4-month period, as did the number of atypical cells in the breast fluid (Petrakis et al. 1996). In the other study, McMichael-Phillips et al. (1996) found that the rate of DNA synthesis by breast cells taken from biopsies of normal breast tissue from women with benign or malignant breast disease was enhanced by 2 weeks of soyabean feeding. Although increased cell proliferation has traditionally been regarded as a factor increasing cancer risk, recent work with the non-steroidal anti-inflammatory drug, sulindac, calls this notion into question. Sulindac increases colon cell proliferation in mice but decreases chemically-induced colon tumours (Moorghen et al. 1998). In the case of soyabean, perhaps the increase in cell proliferation is a compensatory response to an increase in apoptosis, as high doses of genistein have been shown to induce apoptosis in vitro (Shao et al. 1998). 
Although the clinical implications of these studies in premenopausal women are under debate, when the in vitro, animal, and human data are considered, it is difficult to conclude that soyabean and/or isoflavones are necessarily anti-oestrogenic in premenopausal women. As noted previously, however, genistein inhibits the growth of both oestrogen receptor-positive and-negative breast cancer cells (Peterson \& Barnes, 1991). Thus, even without exerting antioestrogenic effects, soyabean/genistein may decrease breast cancer risk through non-hormonal mechanisms (see earlier and Fig. 5).

Epidemiology. Although several epidemiological studies have considered the relationship between soyabean intake and breast cancer risk, most were conducted before the increased interest in the potential anticancer effects of soyabean foods. Consequently, especially in the earlier studies, some concern exists about the completeness of the dietary soyabean data. Not surprisingly, nearly all of the epidemiological studies were conducted in Asia.

The first published study, conducted in Japan, was a case-control study involving 212 cases and equal numbers of hospitalized and neighbourhood controls, that was actually designed to examine the effects of dietary fat on breast cancer risk (Hirohata et al. 1985). No association was noted between fat intake from soyabean products and cancer risk, although specific information on soyabean intake was not provided. In a prospective study in Hawaii involving nearly 7000 subjects, Nomura et al. (1978) used the soyabean intakes of the men in this cohort as a surrogate for their wives' intakes to examine the effect of soyabean on breast cancer risk. Dietary uptake was recorded during two different time periods, 1965-8 and 19715. No association during the first time period was found, but during the second period, an inverse association was noted between intake of miso soup and cancer risk and a trend for a decreased risk for tofu intake. In agreement with these findings, in a prospective study, Hirayama (1986) found a significant graded inverse association between the intake of soyabean paste soup and subsequent risk of breast cancer among 142857 women in Japan followed for 17 years.

More recently, a case-control study by Lee et al. (1991) in Singapore ( $n 200$ cases, 420 controls) found that the regular consumption of soyabean foods was associated with a marked decreased risk of breast cancer in premenopausal women (upper fifth $v$. lowest fifth of the intake of total soyabean products; odds ratio $0.39,95 \%$ CI $0.19,0.77 ; P<0.02$ ), but not in postmenopausal women. Similarly, a Japanese case-control study ( $n 1186$ cases, 23163 controls) also found that soyabean intake (tofu intake $\geqq 3$ times/week $v$. $<3$ times/week) was associated with a decreased risk of breast cancer in premenopausal women (odds ratio 0.81 , $95 \%$ CI $0.65,0.99 ; P<0.05)$, but not postmenopausal women (Hirose et al. 1995). In contrast to these studies, a case-control study involving two different locations in China, Shanghai ( $n$ 534 cases, 534 controls) and Tianjin (n 300 cases, 300 controls), failed to find an association between soyabean food intake and breast cancer risk in either pre- or postmenopausal women (Yuan et al. 1995).

The only case-control study ( $n 596$ cases, 958 controls) thus far conducted in the USA to examine the relationship between soyabean intake and breast cancer risk found that tofu consumption was protective in both pre- (adjusted odds ratio 0.67) and postmenopausal Asian women (adjusted odds ratio 0.60) (Wu et al. 1996). However, the overall intake of tofu among the subjects in this study was relatively low; the highest quartile of intake included women who consumed tofu as little as fifty-five times/year. Also, tofu was protective primarily in Asian women born in Asia who migrated to the West and not in Asians born in the USA (Wu et al. 1998). Finally, in the prospective Iowa Women's Study involving over 34000 women, after 8 years of follow-up, tofu intake was associated with a modest decrease (adjusted relative risk $0 \cdot 76$; no consumption $v$. any consumption) in postmenopausal breast cancer risk. This differ- 
ence was not statistically significant $(P=0 \cdot 22)$ (Greenstein et al. 1996). Not unexpectedly, however, only $2.9 \%$ of the cohort reported eating any tofu.

In addition to the limited number of epidemiological studies that quantified soyabean intake, Ingram et al. (1997), in a study involving 144 pairs of cases and population controls matched for age and area of residence, found an inverse relationship between the risk of both pre- and postmenopausal breast cancer and the urinary excretion of isoflavonoids (three $24 \mathrm{~h}$ collections; for cases, urine samples were collected before surgery). After controlling for age at menarche, alcohol consumption and fat intake, the adjusted odds ratio (lowest $v$. highest quartile) for equol, an isoflavan, was $0.27(P=0.009)$. However, urinary excretion of genistein was not measured and the interassay $\mathrm{CV}$ for the control urine pool sample for the individual phyto-oestrogens ranged from $10.9 \%$ to $42.6 \%$. Also, no markers were included to assess the completeness of urine collections. Perhaps more importantly, based on the urinary collection of daidzein and equol, soyabean consumption even in the highest quartile of intake was quite modest.

Animal studies. Several animal studies have examined the effect of diets containing soyabean isoflavones on experimental mammary cancer (Table 5); four studies used diets that included soyabean-protein isolate ( $>90 \%$ soyabean protein), four non-fermented, whole soyabean products, two miso, and two isoflavones. Overall, these studies provide modest support for a protective effect of soyabean/isoflavones.

Of the four studies using soyabean protein isolate, two found a protective effect (Barnes et al. 1990; Hawrylewicz et al. 1991), whereas two did not (Carroll, 1975; Hsueh \& Park, 1990). However, neither study in which protective effects were observed reported a reduction in tumour incidence. Also, in one of those studies (Hawrylewicz et al. 1991) the addition of methionine to the soyabean diet eliminated much of the difference in tumour number, although tumour volume was still significantly reduced.

Each of the four studies that used non-fermented, whole soyabean products reported protective effects (Troll et al. 1980; Gridley et al. 1983; Barnes et al. 1990; Gotoh et al. 1998b). In the study by Troll et al. (1980), however, raw soyabeans were used and the body weight of soyabean-fed rats was $10 \%$ lower than that of control animals. Also, no effects on tumour incidence were found in any of the other three studies. In the study by Barnes et al. (1990), although tumour number was reduced by approximately $50 \%$, no dose response was observed among the three different diets containing 50, 100 and $200 \mathrm{~g}$ soyabean $/ \mathrm{kg}$ diet). Furthermore, the reduction of tumour number in the study by Gotoh et al. (1998b) appeared to be a function primarily of a delay in tumour appearance. Finally, although Gridley et al. (1983) found that textured soyabean protein did slightly increase the latency period for spontaneous tumours, final cancer incidence was not affected.

Two studies incorporated the fermented soyabean product, miso, into their laboratory diets. In one study, Baggott et al. (1990) found that the number of dimethylbenz(a)anthraceneinduced mammary tumours was decreased by approximately $30 \%$ in rats fed on a diet containing $200 \mathrm{~g}$ miso/kg diet. In the other study, by Gotoh et al. (1998b), a diet containing $100 \mathrm{~g}$ miso/kg diet reduced $\mathrm{N}$-nitroso-N-methylurea (MNU)-induced mammary tumour number by about $50 \%$. As pointed out earlier, however, tumour inhibition appeared to be related to a delay in tumour appearance in the rats consuming whole soyabeans. In a follow-up study (Gotoh et al. 1998a), a diet containing $100 \mathrm{~g}$ miso/kg diet was again shown to be effective in reducing tumour number by about $50 \%$. In addition, tamoxifen also significantly reduced tumour number, and the combination of tamoxifen and miso acted synergistically to inhibit tumour development. This combination significantly reduced both tumour incidence and number. The authors speculated that the increase in the number of oestrogen receptors in the tumour 


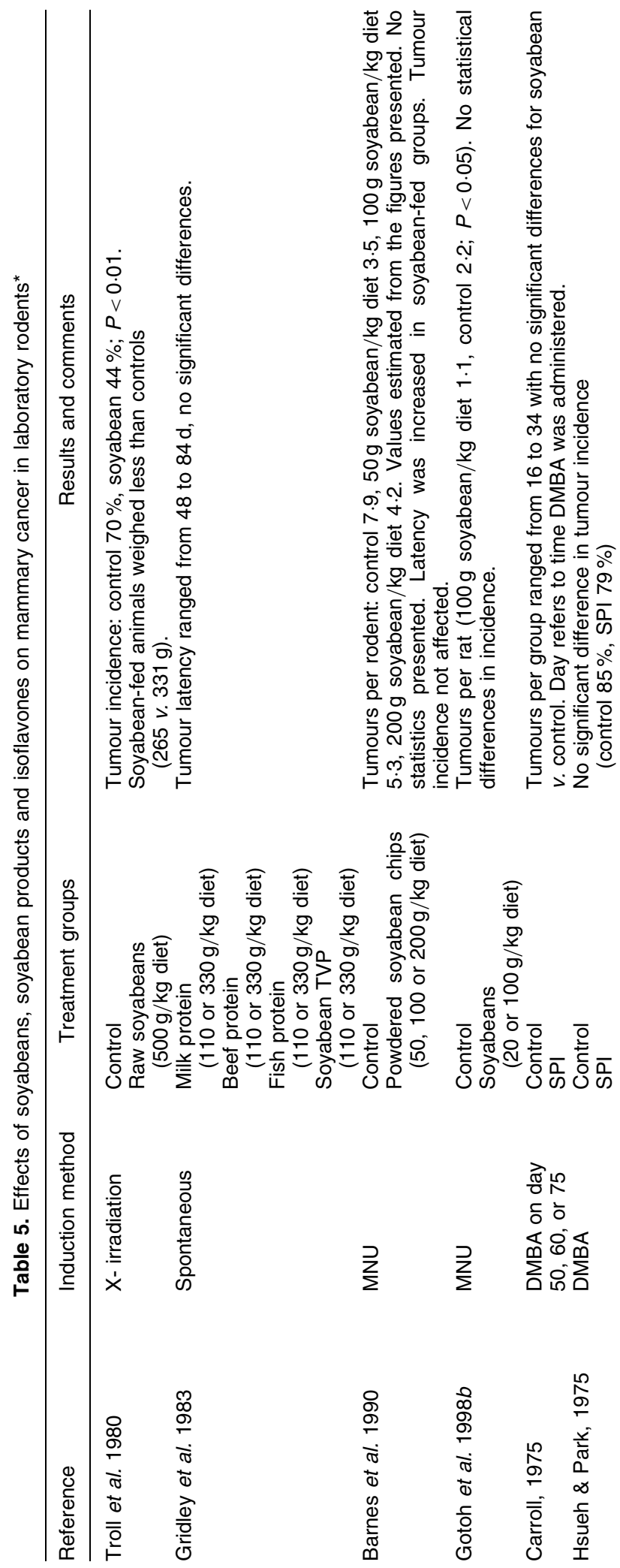


Effects of phyto-oestrogens on tissues
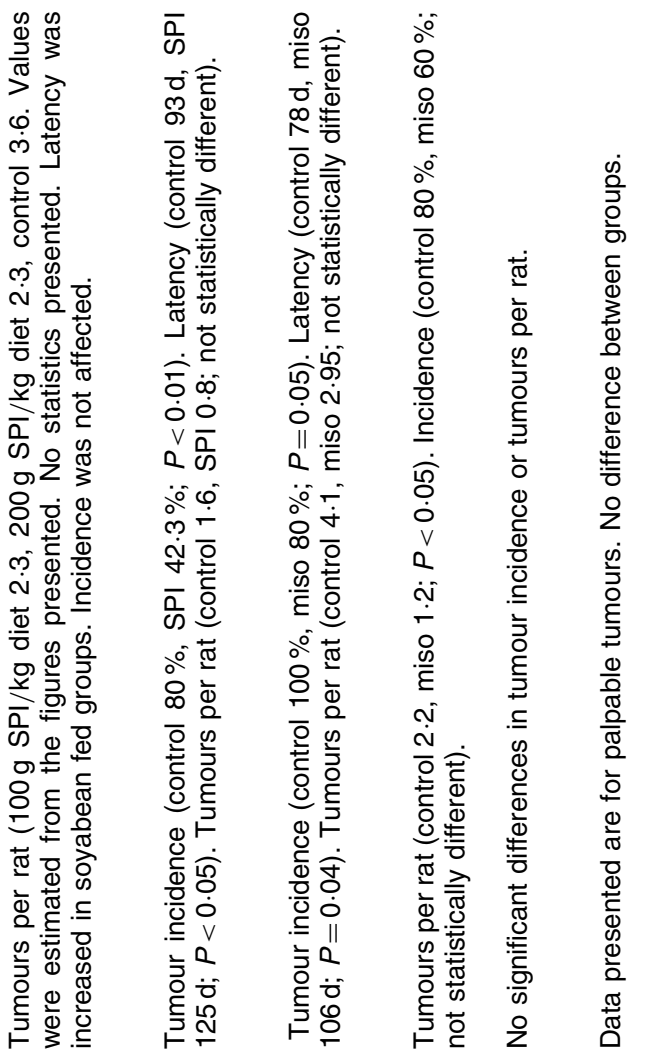

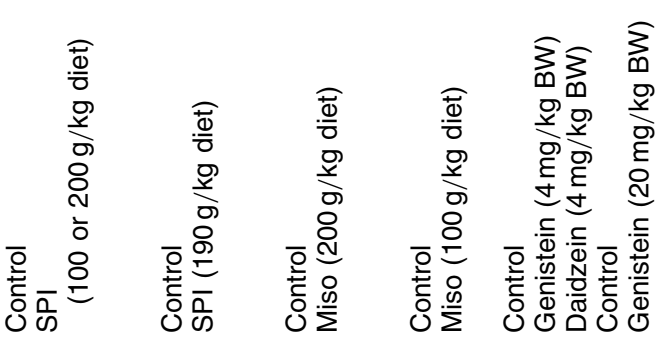

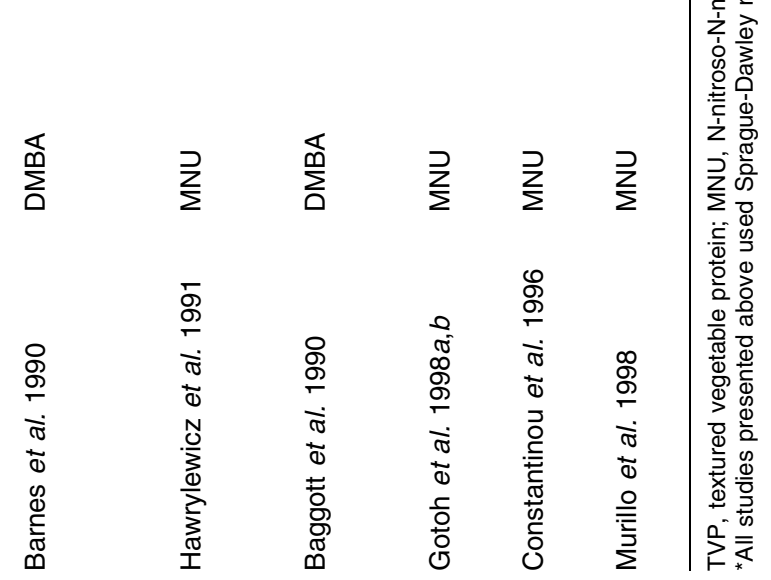


increased the hormone dependency of the tumours, thereby potentiating the effects of the antioestrogen, tamoxifen. Furthermore, in a study designed to examine possible therapeutic effects, the combination of tamoxifen and miso significantly inhibited tumour size, when administered after tumours had already formed, in comparison with the control and tamoxifen groups. Interestingly, Baggott et al. (1990) attributed the protective effects of miso to the high $\mathrm{Na}$ content of this food.

An additional two studies examined the effects of isolated isoflavones on chemically-induced mammary cancer in mature animals. Constantinou et al. (1996) found that neither isolated genistein $(0.8 \mathrm{mg} / \mathrm{d})$ nor daidzein affected MNU-induced mammary tumour incidence. Although both isoflavones reduced tumour number by approximately $20 \%$, this reduction was not statistically significant. Similarly, Murillo et al. (1998) found that genistein had no effect on MNU-induced mammary carcinogenesis. When genistein was combined with the synthetic isoflavone, ipriflavone, which also was ineffective by itself, tumour number was reduced by approximately $50 \%$.

In contrast to the unimpressive effects of isoflavones in adult animals, several reports have shown that early exposure, during either the neonatal or prepubertal period of life, to genistein (subcutaneous or dietary administration) markedly inhibits the development of dimethylbenz(a)anthracene-induced mammary tumours in rodents and increases the latency period (Brown \& Lamartiniere, 1995; Lamartiniere et al. 1995; Murrill et al. 1996). Genistein appears to reduce carcinogenesis by stimulating mammary development and making this tissue less sensitive to the carcinogenic effects of dimethylbenz(a)anthracene. Finally, genistein $(0.75 \mathrm{~g} / \mathrm{kg}$ diet) was found to stimulate the growth of MCF-7 (human breast cancer cell line) cells implanted into OVX athymic mice (Hsieh et al. 1996). The growth of oestrogen-independent MDA-MB-231 cells, a human breast cancer cell line, however, was inhibited by a high $(3 \mathrm{~g} / \mathrm{kg} \mathrm{diet})$, but not a low $(0.75 \mathrm{~g} / \mathrm{kg} \mathrm{diet})$, dose of genistein, although food intake (but not body weight) was reduced by $10 \%$ at the higher level of genistein (Santell et al. 1998).

Overall strength of the evidence for breast cancer. Although an intriguing hypothesis, the scientific evidence is only modestly supportive that the adult consumption of soyabean reduces breast cancer. The limited epidemiological data are somewhat supportive of the hypothesis, but mostly for premenopausal breast cancer. In fact, one case-control study (Wu et al. 1996) found soyabean intake to be inversely related to risk of postmenopausal breast cancer whereas three studies that included four different populations did not (Lee et al. 1991; Hirose et al. 1995; Yuan et al. 1995). Furthermore, in the one study in which soyabean was protective against postmenopausal breast cancer, protection was limited primarily to Asian immigrants, not USA-born Asians. Although Ingram et al. (1997) found the urinary excretion of equol to be inversely related to breast cancer risk, it would appear that overall soyabean intake in that study was quite low. Also, unfortunately, in general in western populations it is difficult to control for all differences between soyabean food consumers and non-consumers that potentially affect breast cancer risk since significant amounts of soyabean foods are not commonly consumed. Perhaps soyabean intake contributes to the low breast cancer mortality rates in Asian countries, not simply because of the consumption of soyabean foods in adulthood, but because of the soyabean foods these women first consumed as young girls.

The most impressive evidence comes from the animal studies showing that exposure to genistein during the early stages of life reduces the later development of chemically-induced mammary cancer. However, findings from studies of adult animals in which isolated isoflavones were administered were not impressive. In general, those studies showing a reduction in carcinogenesis found only that tumour number, not tumour incidence, was affected. Also as discussed previously, there were concerns about many of the studies in which soyabean was shown to be protective. 
Clearly, genistein inhibits both oestrogen-dependent and oestrogen-independent breast cancer cells in vitro. However, the genistein concentration required to inhibit cell growth may be higher than the concentration that can be achieved in vivo in humans consuming soyabean foods and is probably higher than the genistein concentration of free-living Japanese people. A plasma genistein concentration of $276 \mathrm{nmol} / 1$ was observed in free-living Japanese men ( $n$ 14) (Adlercreutz et al. 1993), but in humans fed on soyabean foods and isolated genistein, plasma genistein concentrations have reached the low micromolar level (Xu et al. 1994, 1995; King \& Bursill, 1998). However, most of the genistein molecules in plasma are either bound to protein (Arnold et al. 1996; Martin et al. 1996) or conjugated with glucuronic acid (Adlercreutz et al. 1995) and are, therefore, likely to be biologically inactive. It is worth noting, however, that Peterson \& Barnes (1996) found that much lower genistein concentrations are required to inhibit the growth of non-transformed human breast epithelial cells in comparison with breast cancer cells.

It is clear therefore that given the potent in vitro effects of genistein, and the protective effects shown by some animal and epidemiological studies, little question remains that the relationship between soyabean intake and breast cancer risk warrants further investigation.

\section{Prostate cancer}

Prostate cancer mortality rates vary markedly among countries. An interesting observation related to the occurrence of prostate cancer is that clinical prostate cancer rates vary much more than the rates of latent prostate cancer. For example, the incidence of clinical prostate cancer in the USA among white men is 10-15-fold higher than the Japanese rate, whereas the overall incidence of latent prostate cancer is only about $50 \%$ higher (Yatani et al. 1989). Also, recent work suggests that the Japanese incidence of prostate cancer may actually be under-diagnosed by as much as $80 \%$, making the true ratio of incidence to mortality much higher in Japan than in the West (Shibata et al. 1997). These observations suggest that in some populations, such as the Japanese, the growth of prostate tumours is slower and/or that the onset of prostate tumours occurs later in life. Speculation abounds that the intake of soyabean foods may be one factor contributing to the low Japanese prostate cancer mortality rate, although the data in support of this hypothesis, while intriguing, are limited.

Epidemiological studies. Not surprisingly, limited human data exist upon which to evaluate the soyabean-prostate cancer hypothesis, as only a few epidemiological studies have been conducted in this area. In a Japanese cohort, no significant association between soyabean paste soup and prostate cancer risk (Hirayama, 1979) was noted nor was a consistent relationship for miso soup with prostate cancer evident when comparing cancer patients with patients with hyperplastic disease and controls (Oishi et al. 1988). In contrast, a prospective study by Severson et al. (1989) involving 7999 men in Hawaii who were followed for 18-21 years found that the consumption of tofu was associated with a markedly reduced risk of prostate cancer $\left({ }^{2} 1 /\right.$ week $v .{ }^{3} 5 /$ week; age- adjusted relative risk $\left.0 \cdot 35\right)$, although this difference did not quite reach statistical significance $(P=0.054)$, and the number of men with tumours in each of the tertiles was quite small.

Of potential relevance to the effects of isoflavones on prostate cancer risk is the finding that not only are isoflavone levels higher in prostatic fluid in men from soyabean food-consuming countries but that isoflavones appear to be concentrated by about twofold in the prostatic fluid relative to plasma (Morton et al. 1997). Also worthy of note is a recent report that significant apoptosis occurred in the prostatic specimen from a man with adenocarcinoma who had taken 
isoflavones $(160 \mathrm{mg} / \mathrm{d})$ derived from red clover (Trifolium pratense) one week before surgery (Stephens, 1997). The red clover extract contained both genistein and daidzein as well as the methylated isoflavones, biochanin-A and formononetin, from which genistein and daidzein, respectively, are derived. Finally, in a short-term study by S Barnes (unpublished results), soyabean intake did not affect prostate-specific antigen levels in men with elevated prostatespecific antigen levels.

In vitro effects of genistein. Genistein inhibits the growth of both androgen-dependent and androgen-independent prostate cancer cells in vitro (Peterson \& Barnes, 1993; Naik et al. 1994; Kyle et al. 1997). Also, as noted previously, independent of cell growth, genistein has been shown to inhibit the metastatic potential of prostate cancer cells, an effect that is associated with a decrease in the tyrosine phosphorylation of an unidentified protein (Santibáñez et al. 1997).

In addition to the effects of genistein on signal transduction noted previously, other mechanisms by which genistein/isoflavones could reduce prostate cancer risk also are operating. For example, oestrogens have been used successfully as a form of hormone therapy for metastatic prostate cancer (Pienta \& Esper, 1993); thus, theoretically, the oestrogenic effects of isoflavones may be protective. Also, some data indicate that in genital skin fibroblasts and benign hyperplastic prostate tissue, genistein inhibits the activity of $5 \alpha$-reductase (EC 1.1.1.64), the enzyme that converts testosterone into dihydrotestosterone, which stimulates the growth of prostate tissue (Evans et al. 1995). Ross et al. (1992) have shown that biomarkers of $5 \alpha$ reductase activity are higher in Caucasian and black men compared with Japanese subjects, a finding that may contribute to differences in prostate cancer rates between these populations. The in vitro data from Evans et al. (1995) are consistent with findings from Lu et al. (1996b), who reported that after one month of soyabean milk consumption (1.04 litres/d), serum levels of $3 \alpha, 17 \beta$-androstanediol glucuronide, a metabolite of dihydrotestosterone, were significantly reduced.

Animal studies. Only recently has the effect of soyabean on prostate cancer in laboratory animals been studied. One study relevant to this topic, but which did not involve prostate cancer per se, found that after 9 months of feeding a diet containing soyabean to Han-NMRI mice, the incidence of prostatic dysplasia, which may be viewed as a pre-neoplastic prostate lesion, was markedly reduced compared with the incidence in mice not fed on soyabean (30\% v. $80 \%, P<0.04$ ) (Mäkelä et al. 1995). At 12 months, however, the difference between the two groups was reduced $(64 \%$ v. $86 \%)$. These findings are consistent not only with the epidemiological data noted above, but also with the results of a study of MNU- induced prostate tumours in Lobund-Wistar rats (Pollard \& Luckert, 1997). Rats fed on a diet containing soyabean, but with a very low level of isoflavones, had latency periods of 7.3 (pre-MNU group) and 9.3 months (post-MNU group), compared with 10.0 (pre-MNU group) and 10.6 months (post-MNU group) for animals fed on a diet containing soyabean with a high isoflavone content (Fig. 10).

Five studies were identified that examined the effect of soyabean/genistein on tumour development in rats implanted with prostate cancer cells (Naik et al. 1994; Wang et al. 1995; Schleicher et al. 1996; Zhang et al. 1997a; Zhou et al. 1998). Four of these studies, all of which have been published in abstract form only, reported protective effects. Zhang et al. (1997a) found that in rats fed on a diet containing soyabean flour $(330 \mathrm{~g} / \mathrm{kg}$ diet $)$ and implanted with Dunning R3327 PAP (rat prostate adenocarcinoma) tumours, tumour growth was significantly retarded at 16 weeks compared with animals fed on the control diet. Similarly, Schleicher $e$ a al. (1996) found that genistein $(50 \mathrm{mg} / \mathrm{kg}$ body weight), given under the skin in the dorsal scapular area every $12 \mathrm{~h}$ starting at the time of tumour cell transplantation, inhibited the development of 


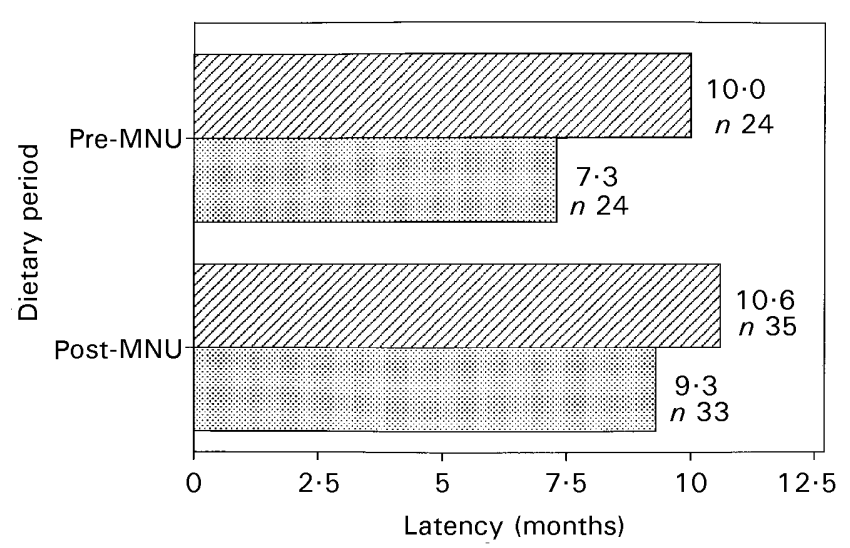

Fig. 10. Tumour latency period in rats fed on high and low isoflavone-containing diets. Rats were fed on a diet that included $200 \mathrm{~g} / \mathrm{kg}$ soyabean protein isolate containing either $1.27 \mathrm{mg}$ genistein and $0.42 \mathrm{mg}$ daidzein per g protein (high isoflavone, (娄)) or $0.077 \mathrm{mg}$ genistein and $0.025 \mathrm{mg}$ daidzein per g protein (low isoflavone, (国)) Tumours were initiated by inoculation with a single dose of $\mathrm{N}$-nitroso-N-methylurea (MNU) followed by two subcutaneous implants of testosterone propionate. Diets were fed either before or following MNU administration. Trials were terminated 14 months after onset. Adapted from Pollard \& Luckert (1997).

prostate tumours in rats implanted with prostate carcinoma cells. Rats given genistein developed fewer tumours and fewer invasive tumours and no genistein-treated animals developed lung metastases. In agreement with these studies, Zhou et al. (1998) found that the addition of an isoflavone rich concentrate to an AIN-76 diet (Anonymous, 1977) significantly reduced tumour volume in SCID (Severe, Combined ImmunoDeficiency) mice inoculated subcutaneously with $2 \times 10^{6} \mathrm{LNCaP}$ (human prostate adenocarcinoma cell line) cells. Finally, Wang et al. (1995) found that dietary genistein $(1 \mathrm{~g} / \mathrm{kg}$ diet), when added to a high-fat (40.5\% of energy) diet, inhibited the growth of LNCaP cells implanted into nude mice.

Insight into a possible mechanism for the inhibitory effects of genistein against implanted prostate cancer cells comes from Dalu et al. (1996) who found that in Lobund-Wistar rats, dietary genistein $(1 \mathrm{~g}$ genistein $/ \mathrm{kg}$ diet $)$ decreased the weight of the dorsolateral and ventral prostates and inhibited the expression of tyrosine-phosphorylated proteins. This study is the first to demonstrate that, in vivo, genistein inhibits a key cellular pathway. Related to this finding are those of Geller et al. (1998) who found that genistein inhibited the incorporation of $\left[{ }^{3} \mathrm{H}\right]$ thymidine (a measure of tissue growth) in a dose-dependent fashion (at concentration ranging from $1-15 \mu \mathrm{g} / \mathrm{ml}$ ) by $44 \%$ and $86 \%$ in cultured benign prostate hypertrophy tissue.

In contrast to the favourable results discussed above, Naik et al. (1994) found that, although genistein inhibited prostate cancer cell growth in vitro, when Copenhagen rats were injected in the right flank with the metastatic MAT-Lylu prostate cancer cell line, oral doses of genistein of $0.07,0.143$ and $0.285 \mathrm{mg} / \mathrm{kg}$ body weight per $\mathrm{d}$ did not inhibit the development of prostate tumours. Higher doses of genistein $(0.143,0.285$ and $0.428 \mathrm{mg} / \mathrm{kg}$ body weight per d) injected intraperitoneally also had little effect on tumour growth. The dietary levels used by Naik et al. (1994) were much lower than the levels used in the studies in which protective effects were observed, but they more closely approximate human dietary intake. 
Overall strength of the evidence for prostate cancer. The evidence that soyabean reduces prostate cancer risk is limited, but the available data tend to be more supportive of a benefit in terms of a reduction in prostate cancer risk than they are for breast cancer although this relationship is still quite speculative. Only a few epidemiological studies have examined this issue, and although one study did suggest that tofu intake was protective against prostate cancer, the association did not reach statistical significance (Severson et al. 1989). Several studies did find that soyabean/genistein inhibited the growth of prostate cancer cells implanted into rodents (Wang et al. 1995; Schleicher et al. 1996; Zhang et al. 1997a; Zhou et al. 1998), and one study found that genistein inhibited a key cellular pathway in vivo (Dalu et al. 1996). However, when a relatively low dose of genistein (in comparison with these studies) was used, Naik et al. (1994) did not observe growth inhibition in vivo. A very intriguing finding reported by Morton et al. (1997) is that, relative to plasma, isoflavones appear to be concentrated in the prostatic fluid. This difference in concentration suggests that the relatively high levels of genistein required to inhibit prostate cancer cell growth in vitro and in vivo may be applicable to humans consuming soyabean foods.

\section{Discussion}

The two primary observations of low breast and prostate cancer rates in Asian countries, where soyabean foods are consumed at high levels, and high isoflavone content of soyabeans raised initial interest in the relationship between soyabean food intake and cancer risk. However, only within the past 10 years has the diet-prostate cancer linkage been seriously investigated and establishing diet-cancer relationships has proved to be difficult, in part because many of the data relevant to the soyabean-cancer relationship are conflicting.

Overall, the evidence is more supportive for a protective effect against prostate cancer than breast cancer. In addition to the evidence already presented, several intriguing observations about the possible anticancer effects of soyabean/isoflavones related to breast, prostate, and other cancers make further research in this area compelling. For example, genistein has been shown to inhibit angiogenesis in vitro (Fotsis et al. 1993). Although the concentration of genistein initially reported to inhibit angiogenesis $\left(\mathrm{IC}_{50}, 150 \mu \mathrm{mol} / \mathrm{l}\right)$ is certainly much higher than the genistein concentration likely to be achieved in vivo, more recent work has shown that a much lower $\left(\mathrm{IC}_{50}, 8 \mu \mathrm{M}\right)$ genistein concentration is effective in inhibiting angiogenesis (Adlercreutz \& Mazur, 1997). A possible explanation for the higher genistein concentration required to inhibit angiogenesis in the earlier report may have resulted from incomplete solubilization of genistein in the media.

Results from several recent animal studies also suggest that soyabean/isoflavones may inhibit tumour metastases (Yan et al. 1997, 1998; Menon et al. 1998), including the metastases of human breast cancer cells (Connolly et al. 1997). In addition, daidzein has recently been shown to enhance immune function in vitro (Wang et al. 1997) and in animals (Zhang et al. 1997b), although Hendrich et al. (1998) did not find an effect of short-term (7 d) soya milk consumption on natural killer cell activity in young adults. Finally, results from a preliminary human study indicated that short-term soya milk consumption reduced lymphocyte DNA damage (Mitchell \& Collins, 1998). Thus, a variety of potential mechanisms exists through which soyabean foods may inhibit the cancer process that are equally applicable to a variety of cancers (Table 3). Human studies in which the effects of soyabean consumption on biomarkers 
of cancer risk are examined are sorely needed and more research in general is needed before anything approaching a firm conclusion can be made.

\section{Overall conclusions}

Investigations of phyto-oestrogens over the previous decade have demonstrated that these isoflavone molecules have diverse actions on mammalian cells, largely related to their oestrogen-mimetic properties.

Classical genomic actions of oestrogens have been used to explain the positive effects of these steroid molecules on both cardiovascular and bone tissues. Similarly, the potential for stimulation of growth of cancer cells in breast and uterine tumours is probably due to their effects on protein expression. Although the phyto-oestrogens were originally discovered because of their ability to mimic the actions of oestrogens on reproductive tissues in livestock, more recent research suggest that many potential effects of both oestrogens and phyto-oestrogens may be mediated by either cell-surface steroid receptors or molecules that belong to intracellular second-messenger systems. Understanding these alternative mechanisms of action will be critical for defining the role of phyto-oestrogens for both their beneficial and, potentially, adverse effects.

Human studies that are underway will probably demonstrate whether short-term consumption of phyto-oestrogens can produce health-promoting effects on tissue function and clarify effective doses for various organ systems. The epidemiological studies involving high soyabean-consuming Asian populations have been based on individuals with a lifetime pattern of daily intakes of phyto-oestrogen-containing foods from diverse soyabean products. The evidence that soyabean, with its phyto-oestrogens, is beneficial for cardiovascular diseases and its risk factors seems convincing. Likewise, the beneficial effects of soyabean phyto-oestrogens on bone are rather consistent, although longer term studies are required to be conclusive. Whether favourable effects of soyabean phyto-oestrogens on bone and cancer risk exist will require further information to develop a consensus.

\section{References}

Adlercreutz H, Markkanen H \& Watanabe S (1993) Plasma concentrations of phyto-oestrogens in Japanese men. Lancet 342, 1209-1210.

Adlercreutz H \& Mazur W (1997) Phyto-estrogens and western diseases. Annals of Medicine 29, 95-120.

Adlercreutz H, van der Wilt J, Kinzel J, Attalla H, Wähalä K, Mäkelä T, Hase T \& Fotsis T (1995) Lignan and isoflavonoid conjugates in human urine. Journal of Steroid Biochemistry and Molecular Biology 52, 97-103.

Akiyama T, Ishida J, Nakagawa S, Ogawara H, Watanabe S, Itoh N, Shibuya M \& Fukami Y (1987) Genistein, a specific inhibitor of tyrosine-specific protein kinases. Journal of Biological Chemistry 262, 5592-5595.

Anderson JJ, Ambrose WW \& Garner SC (1995a) Orally dosed genistein from soy and prevention of cancerous bone in two ovariectomized rat models. Journal of Nutrition 125, 799S Abstr.

Anderson JJB, Ambrose WW \& Garner SC (1998) Biphasic effects of genistein on bone tissue in the ovariectomized, lactating rat model. Proceedings of the Society for Experimental Biology and Medicine 217, 345-350.

Anderson JJB \& Garner SC (1997) The effects of phyto-estrogens on bone. Nutrition Research 20, $220-224$.

Anderson JJB \& Miller CP (1998) Lower lifetime estrogen exposure among vegetarians as a possible risk factor for osteoporosis: a hypothesis. Vegetarian Nutrition 2, 4-12.

Anderson JJB, Thomsen K \& Christiansen C (1987) High protein meals, insular hormones, and urinary calcium excretion in human subjects. In Osteoporosis 1987, pp. 240-245 [C Christiansen, JS Johnson and B Riis, editors]. Copenhagen, Denmark: Osteopress ApS.

Anderson JW, Johnstone BM \& Cook-Newell ME (1995b) Meta-analysis of the effects of soy protein intake on serum lipids. New England Journal of Medicine 333, 276-282.

Anderson RL \& Wolf WJ (1995) Compositional changes in trypsin inhibitors, phytic acid, saponins and isoflavones related to soybean processing. Journal of Nutrition 125, $581 \mathrm{~S}-588 \mathrm{~S}$ 
Anonymous (1977) Report of the American Institute of Nutrition ad hoc Committee on Standards for Nutritional Studies. Journal of Nutrition 107, 1340-1348.

Anthony MS \& Clarkson TB (1998) Comparison of soy phyto-estrogens and conjugated equine oestrogens on atherosclerosis progression in postmenopausal monkeys. Circulation 97, 829 Abstr.

Anthony MS, Clarkson TB, Bullock BC \& Wagner JD (1997) Soy protein versus soy phyto-estrogens in the prevention of diet-induced coronary artery atherosclerosis of male cynomolgus monkeys. Arteriosclerosis, Thrombosis and Vascular Biology 17, 2524-2531.

Anthony MS, Clarkson TB, Hughes CL, Morgan TM \& Burke GL (1996) Soybean isoflavones improve cardiovascular risk factors without affecting the reproductive system of peripubertal rhesus monkeys. Journal of Nutrition 126, 43 50 .

Anthony MS, Clarkson TB \& Williams JK (1998) Effect of soy isoflavones on atherosclerosis potential mechanisms. American Journal of Clinical Nutrition 68, 1390S-1393S.

Arjmandi BH, Alekel L, Hollis BW, Amin D, Stacewicz-Sapuyntzakis M, Guo P \& Kukreja SC (1996) Dietary soybean protein prevents bone loss in an ovariectomized rat model of osteoporosis. Journal of Nutrition 126, 161-167.

Arnold SF, Collins BM, Robinson MK, Guillette LJ Jr \& McLachlan JA (1996) Differential interaction of natural and synthetic oestrogens with extracellular binding proteins in a yeast oestrogen screen. Steroids 61, 642-646.

Arts J, Kuiper GGJM, Janssen JMMF, Gustafsson JÅ, Löwik CWGM, Pol HAP \& Van Leeuwen JPTM (1997) Differential expression of estrogen receptors $\alpha$ and $\beta$ mRNA during differentiation of human osteoblast SV-HFO cells. Endocrinology 138, 5067-5070.

Asahi M, Yanagi S, Ohta S, Inazu T, Sakai K, Takeuchi F, Taniguchi T \& Yamamura H (1992) Thrombin-induced human platelet aggregation is inhibited by protein-tyrosine kinase inhibitors, ST638 and genistein. FEBS Letters 309, $10-14$.

Baggott JE, Ha T, Vaughn WH, Juliana MM, Hardin JM \& Grubbs CJ (1990) Effect of miso (Japanese soybean paste) and $\mathrm{NaCl}$ on DMBA-induced rat mammary tumors. Nutrition and Cancer 14, 103-109.

Balmir F, Staack R, Jeffrey E, Berber-Jimenez MD, Wang L \& Potter SM (1996) An extract of soya flour influences serum cholesterol and thyroid hormones in rats and hamsters. Journal of Nutrition 126, 3046-3053.

Barnes S, Grubbs C, Setchell KDR \& Carlson J (1990) Soybeans inhibit mammary tumors in models of breast cancer. In Mutagens and Carcinogens in the Diet, pp. 239-253 [MW Pariza, H-U Aeschbacher, JS Felton and S Sato, editors]. New York, NY: Wiley Liss.

Baum JA, Teng H, Erdman JW, Weigel RM, Klein BP, Persky VW, Freels S, Surya P, Bakhit RM, Ramos E, Shay NF \& Potter SM (1998) Long-term intake of soy protein improves blood lipid profiles and increases mononuclear cell LDL receptor mRNA in hypercholesterolemic postmenopausal women. American Journal of Clinical Nutrition $\mathbf{6 8}$, $545-551$.

Bennetts HW, Underwood EJ \& Shier FL (1946) A specific breeding problem of sheep on subterranean clover pastures in western Australia. Australian Veterinary Journal 22, 2-12.

Benten WPM, Lieberherr M, Giese G \& Wunderlich F (1998) Estradiol binding to cell surface raises cytosolic free calcium in T cells. FEBS Letters $\mathbf{4 2 2}, 349-353$.

Benten WPM, Lieberherr M, Sekeris CE \& Wunderlich F (1997) Testosterone induces $\mathrm{Ca}^{2+}$ influx via non-genomic surface receptors in activated T cells. FEBS Letters 407, 211-214.

Benvenuti S, Tanini A, Fredianin U, Bianchi S, Masi L, Casano R, Bufalino L, Serio M \& Brandi ML (1991) Effects of ipriflavone on a clonal osteoblastic line. Journal of Bone and Mineral Research 6, 987-996.

Blair HC, Jordan SE, Peterson TG \& Barnes S (1996) Variable effects of tyrosine kinase inhibitors on avian osteoclastic activity and reduction of bone loss in ovariectomized rats. Journal of Cellular Biochemistry 61, 629-637.

Bodine PVN, Henderson RA, Green J, Aronow M, Owen T, Stein GS, Lian JB \& Komm BS (1998) Estrogen receptor- $\alpha$ is developmentally regulated during osteoblast differentiation and contributes to selective responsiveness of gene expression. Endocrinology 139, 2048-2057.

Brown NM \& Lamartiniere CA (1995) Xenoestrogens alter mammary gland differentiation and cell proliferation in the rat. Environmental Health Perspectives 103, 708-713.

Carroll KK (1975) Experimental evidence of dietary factors and hormone-dependent cancers. Cancer Research 35, $3374-3383$.

Cassidy A, Bingham S \& Setchell K (1995) Biological effects of isoflavones in young women: importance of the chemical composition of soyabean products. British Journal of Nutrition 74, 587-601.

Cassidy A, Bingham S \& Setchell KDR (1994) Biological effects of a diet of soy protein rich in isoflavones on the menstrual cycle of premenopausal women. American Journal of Clinical Nutrition 60, 333-340.

Cecchini MG, Fleisch H \& Mühlbauer RC (1997) Ipriflavone inhibits bone resorption in intact and ovariectomized rats. Calcified Tissue International 61, S9-S11.

Chemopreventive Branch and Agent Development Committee (1996) Clinical development plan, genistein. Journal of Cellular Biochemistry 265, 114-126.

Connolly JM, Liu X-H \& Rose DP (1997) Effects of dietary menhaden oil, soy, and a cyclooxygenase inhibitor on human breast cancer cell growth and metastasis in nude mice. Nutrition and Cancer 29, 48-54.

Constantinou A, Kiguchi K \& Huberman E (1990) Induction of differentiation and DNA strand breakage in human HL60 and K-562 leukemia cells by genistein. Cancer Research 50, 2618-2624.

Constantinou AL, Mehta RG \& Vaughan A (1996) Inhibition of N-methyl-N-nitrosourea-induced mammary tumors in rats by the soybean isoflavones. Anticancer Research 16, 3293-3298. 
Coward L, Barnes NC, Setchell KDR \& Barnes S (1993) Genistein, daidzein, and their $\alpha$-glycoside conjugates: antitumor isoflavones in soybean foods from American and Asian diets. Journal of Agricultural and Food Chemistry 41, $1961-1967$.

Cowley SM, Hoare S, Mosselman S \& Parker MG (1997) Estrogen receptors alpha and beta form heterodimers on DNA. Journal of Biological Chemistry 272, 19858-19862.

Crouse JR, Terry JG, Morgan TM, McGill BL, Davis DH, King T, Ellis JE \& Burke GL (1998) Soy protein containing isoflavones reduces plasma concentrations of lipids and lipoproteins. Circulation 97, 816 Abstr.

Dalu A, Haskell J \& Lamartiniere CA (1996) Dietary genistein inhibits protein tyrosine phosphorylation in the dorsolateral prostate of the rat. Proceedings of the Second International Symposium on the Role of Soy in Preventing and Treating Chronic Disease, p. 47. Abstr. no. 10.

Dees C, Foster JS, Ahamed S \& Wimalensa J (1997) Dietary estrogens stimulate human breast cancer cells to enter the cell cycle. Environmental Health Perspectives 105, Suppl. 3, 633-636.

Dodge JA, Glasebrook AL, Magee DE, Phillips DL, Sato M, Short LL \& Bryant HU (1996) Environmental estrogens: Effects of cholesterol lowering and bone in the ovariectomized rat. Journal of Steroid Biochemistry and Molecular Biology 59, $155-161$.

Draper CR, Edel MJ, Dick IM, Randall AG, Martin GB \& Prince RL (1997) Phytoestrogens reduce bone loss and bone resorption in oophorectomized rats. Journal of Nutrition 127, 1795-1799.

Duncan AM, Merz BE, Xu X, Underhill KEW, Phipps WR \& Kurzer MS (1998) Soy isoflavones do not exert hormonal effects in premenopausal women. FASEB Journal 12, A568 Abstr. no. 3295.

Evans BAJ, Griffiths K \& Morton MS (1995) Inhibition of $5 \alpha$-reductase in genital skin fibroblasts and prostate tissue by dietary lignans and isoflavonoids. Journal of Endocrinology 147, 295-302.

Folman Y \& Pope GS (1966) The interaction in the immature mouse of potent estrogens with coumestrol, genistein and other utero-vaginotrophic compounds of low potency. Journal of Endocrinology 34, 215-225.

Foth D \& Cline JM (1998) Effects of mammalian and plant estrogens on mammary glands and uteri of macaques. American Journal of Clinical Nutrition 68, 1413S-1417S.

Fotsis T, Pepper M, Adlercreutz H, Gleischmann G, Hase T, Montesano R \& Schweigerer L (1993) Genistein, a dietaryderived inhibitor of in vitro angiogenesis. Proceedings of the National Academy of Sciences, USA 90, 2690-2694.

Franke AA, Custer LJ, Cerna CM \& Narala KK (1994) Quantitation of phytoestrogens in legumes by HPLC. Journal of Agriculture and Food Chemistry 42, 1905-1913.

Fujio Y, Fumiko Y, Takahashi K \& Shibata N (1993) Responses of smooth muscle cells to platelet-derived growth factor are inhibited by herbimycin-A tyrosine kinase inhibitor+. Biochemical and Biophysical Research Communications 195, 79-83.

Gaub MP, Bellard M, Scheuer I, Chambon P \& Sasson-Corsi P (1990) Activation of the ovalbumin gene by the estrogen receptor involves the fos-jun complex. Cell 63, 1267-1276.

Geller J, Sionit L, Partido C, Lingna L, Tan X, Youngkin T, Nachtsheim D \& Hoffman RM (1998) Genistein inhibits the growth of human-patient BPH and prostate cancer in histoculture. The Prostate 34, 75-79.

Gennari C, Adami S, Agnusdei D, Bufalino L, Cervetti R, Crepaldi G, Di Marco C, Di Munno O, Fantasia L, Isaia GC, Mazzuoli GF, Ortolani S, Passeri M, Serni U \& Vecchiet L (1997) Effect of chronic treatment with ipriflavone in postmenopausal women with low bone mass. Calcified Tissue International 61, S19-S22.

Geynet C, Millet C, Truong H \& Baulier EE (1972) Estrogens and antiestrogens. Hormone antagonists. Gynecologic Investigations 3, 2-29.

Gotoh T, Yamada K, Ito A, Yin H, Kataoka T \& Dohi K (1998a) Chemoprevention of N-nitroso-N-methylurea-induced rat mammary cancer by miso and tamoxifen, alone and in combination. Japanese Journal of Cancer Research 89, $487-495$.

Gotoh T, Yamada K, Yin H, Ito A, Kataoka T \& Dohi K (1998b) Chemoprevention of N-nitroso-N-methylureainduced rat mammary carcinogenesis by soy foods or biochanin A. Japanese Journal of Cancer Research $\mathbf{8 0}$, $137-142$.

Graf E \& Eaton JW (1993) Suppression of colonic cancer by dietary phytic acid. Nutrition and Cancer 19, $11-19$.

Greenstein J, Kushi L, Zheng W, Fee R, Campbell D, Sellers T \& Folsom A (1996) Risk of breast cancer associated with intake of specific foods and food groups. American Journal of Epidemiology 143, S36 Abstr. no. 141.

Gridley DS, Kettering JD, Slater JM \& Nutter RL (1983) Modification of spontaneous mammary tumors in mice fed different sources of protein, fat, and carbohydrate. Cancer Letters 19, 133-146.

Haggins CJ, Martini MC, Slavin JL, Thomas W \& Bancisak BB (1998) Soy supplementation does not affect hormone levels or menstrual cycle length in women with or without oral contraceptives. FASEB Journal 12, A568 Abstr. no. 3296.

Hawrylewicz EJ, Huang HH \& Blair WH (1991) Dietary soybean isolate and methionine supplementation affect mammary tumor progression in rats. Journal of Nutrition 121, 1693-1698.

Helmeste DM \& Tang SW (1995) Tyrosine kinase inhibitors regulate serotonin uptake in platelets. European Journal of Pharmacology 280, R5-R7.

Hendrich S, Xu X, Lu Z, Dickerson S, Cunnick JE \& Murphy PA (1998) Human isoflavone bioavailability during seven days of soymilk feeding, and lack of isoflavone effect of natural killer cell activity. FASEB Journal 12, A874 Abstr. no. 5060 .

Higashi K \& Ogawara H (1994) Daidzein inhibits insulin- or insulin-growth factor-1-mediated signaling in cell cycle progression of Swiss 3 T3 cells. Biochimica et Biophysica Acta 1221, 29-35. 
Hirano T, Oka K \& Akiba M (1989) Antiproliferative effects of synthetic and naturally occurring flavonoids on tumor cells of the human breast carcinoma cell line, ZR-75-1. Research Communications in Chemical Pathology and Pharmacology 64, 69-78.

Hirayama T (1979) Epidemiology of prostate cancer with special reference to the role of diet. National Cancer Institute Monograph 53, 149-155.

Hirayama T (1986) A large scale cohort study on cancer risks by diet — with special reference to the risk reducing effects of green-yellow vegetable consumption. In Diet, Nutrition and Cancer, pp. 41-53 [Y Hayashi, M Nagao, T Sugimara, S Tokayama, L Tomatis, LW Wattenberg and GN Wagen, editors]. Utrecht, The Netherlands: Tokyo/VNU Science Press.

Hirohata T, Shigematsu T, Nomura AMY, Normua Y, Horie A \& Hirohata I (1985) Occurrence of breast cancer in relation to diet and reproductive history: a case-control study in Fukuoka, Japan. National Cancer Institute Monographs 69, 187-190.

Hirose K, Tajima K, Hamajima N, Inoue M, Takezaki T, Kuroisha T, Yoshida M \& Tokudome S (1985) A large-scale hospital-based case-control study of risk factors of breast cancers according to menopausal status. Japanese Journal of Cancer Research 86, 146-154.

Hodgson JM, Croft KD, Puddey IB, Mori TA \& Beillin LJ (1996) Soybean isoflavonoids and their metabolic products inhibit in vitro lipoprotein oxidation in serum. Journal of Nutritional Biochemistry 7, 664-669.

Hodgson JM, Puddey IB, Beillin LJ, Mori TA \& Croft KD (1998) Supplementation with isoflavonoid phytoestrogens does not alter serum lipid concentrations: a randomized controlled trial in humans. Journal of Nutrition 128, 728732 .

Honoré EK, Williams JK, Anthony MS \& Clarkson TB (1997) Soy isoflavones enhance vascular reactivity in atherosclerotic female macaques. Fertility and Sterility 67, 148-154.

Hsieh C-Y, Santell RC, Haslam SZ \& Helferich WG (1998) Estrogenic effects of genistein on the growth of estrogen receptor-positive human breast cancer (MCF-7) cells in vitro and in vivo. Cancer Research 58, 3833-3838.

Hsueh AM \& Park H-S (1990) Quality of dietary protein and chemical carcinogenesis in rats. International News: Fats Oils Related Materials 1, 303 Abstr.

Huff MW, Hamilton RMG \& Carroll KK (1977) Plasma cholesterol levels in rabbits fed low fat, cholesterol-free, semipurified diets: Effects of dietary proteins, protein hydrolysates and amino acid mixtures. Atherosclerosis 28, $187-195$.

Imoto M, Yamashita T, Sawa T, Kurasawa S, Naganawa H, Takeuchi T, Bao- quan Z \& Umezawa K (1988) Inhibition of cellular phosphatidylinositol turnover by psi-tectorigenin. FEBS Letters 230, 43-46.

Ingram D, Sanders K, Kolybaba M \& Lopez D (1997) Phytoestrogens and breast cancer — a case control study. Lancet 350, 990-994.

Jayo MJ, Anthony MS, Register TC, Rankin SE, Vest T \& Clarkson TB (1996) Dietary soy isoflavones and bone loss: a study in ovariectomized monkeys. Journal of Bone and Mineral Research 11, Suppl. 1, S228 Abstr. S555.

Jing Y, Nakaya K \& Han R (1993) Differentiation of promyelocytic leukemia cells HL-60 induced by daidzein in vitro and in vivo. Anticancer Research 13, 1049-1054.

Kamei H, Koide T, Hashimoto Y, Kojima T, Umeda T \& Hasegawa M (1997) Tumor cell growth-inhibiting effects of melanoidins extracted from miso and soy sauce. Cancer Biotherapy \& Radiopharmaceuticals 12, 405-409.

Kennedy AR \& Manzone H (1995) Effects of protease inhibitors on levels of proteolytic activity in normal and premalignant cells and tissues. Journal of Cellular Biochemistry 22, Suppl., 188-194.

King RA \& Bursill DB (1998) Plasma and urinary kinetics of the isoflavones daidzein and genistein after a single soy meal in humans. American Journal of Clinical Nutrition 67, 867-872.

Kirk EA, Sutherland P, Wang SA, Chait A \& LeBoeuf RC (1998) Dietary isoflavones reduce plasma cholesterol and atherosclerosis in C57BL/6 mice but not LDL receptor-deficient mice. Journal of Nutrition 128, 954-959.

Koratkar R \& Rao AV (1997) Effect of soy bean saponins on azoxymethane-induced preneoplastic lesions in the colon of mice. Nutrition and Cancer 27, 206-209.

Kuiper GGJM, Carlsson B, Grandien K, Enmark E, Häggblad J, Nilsson S \& Gustafsson JÅ (1997) Comparison of the ligand binding specificity and transcript tissue distribution of estrogen receptors $\alpha$ and $\beta$. Endocrinology 138, 863870 .

Kuiper GGJM, Enmark E, Pelto-Huikko M, Nilsson S \& Gustafsson JÅ (1996) Cloning of a novel estrogen receptor expressed in rat prostate and ovary. Proceedings of the National Academy of Sciences, USA 93, 5925-5930.

Kuo S-M (1996) Antiproliferative potency of structurally distinct dietary flavonoids on human colon cancer cells. Cancer Letters 110, $41-48$.

Kuruvilla A, Putcha G, Poulos E \& Shearer WT (1993) Tyrosine phosphorylation of phospholipase C concomitant with its activation by platelet-activating factor in a human B cell line. Journal of Immunology 151, 637-648.

Kyle E, Neckers L, Takimoto C, Curt G \& Bergan R (1997) Genistein-induced apoptosis of prostate cancer cells is preceded by a specific decrease in focal adhesion kinase activity. Molecular Pharmacology 51, 193-200.

Lamartiniere CA, Moore JB, Brown NM, Thompson R, Hardin MJ \& Barnes S (1995) Genistein suppresses mammary cancer in rats. Carcinogenesis 16, 2833-2840.

Le Mellay V, Grosse B \& Lieberherr M (1997) Phospholipase C $\beta$ and membrane action of calcitriol and estradiol. Journal of Biological Chemistry 272, 11902-11907.

Lee HP, Gourley L, Duffy SW, Esteve J \& Day NE (1991) Dietary effects on breast-cancer risk in Singapore. Lancet 337, $1197-1200$. 
Lees C \& Ginn TA (1998) Soy protein isolate diet does not prevent increased cortical bone turnover in ovariectomized macaques. Calcified Tissue International 62, 557-558.

Linassier C, Pierre M, Le Peco J-B \& Pierre J (1990) Mechanism of action in NIH-3T3 cells of genistein, an inhibitor of EGF receptor tyrosine kinase activity. Biochemical Pharmacology 39, 187-193.

Lu L-J, Anderson KE, Grady JJ \& Nagamani M (1996a) Effects of soy consumption for one month on steroid hormones in postmenopausal women: implications for breast cancer risk reduction. Cancer Epidemiology, Biomarkers and Prevention 5, 63-70.

Lu L-J, Anderson KE, Grady JJ \& Nagamani M (1996b) Effects of one month soy consumption on circulating steroids in men. Proceedings of the American Association for Cancer Research 37, 270 Abstr. no. 1841.

Machelon V, Nomé F, Grosse B \& Lieberherr M (1996) Progesterone triggers rapid transmembrane calcium influx and/or calcium mobilization from endoplasmic reticulum, via a pertussis-insensitive G-protein in granulosa cells in relation to luteinization process. Journal of Cellular Biochemistry 61, 619-628.

McMichael-Phillips DF, Harding C, Morton M, Roberts ST, Howell A, Potten CS \& Bundred NJ (1998) The effects of soy-protein supplementation on epithelial proliferation in the histologically normal human breast. American Journal of Clinical Nutrition 68, Suppl., 1431S-1436S.

McNicol A (1993) The effects of genistein on platelet function are due to thromboxane receptor antagonism rather than inhibition of tyrosine kinase. Prostaglandins, Leukotrienes and Essential Fatty Acids 48, 379-384.

Mäkelä S, Davis VL, Tally WC, Korkman J, Sala L, Vinko R \& Korach KS (1994) Dietary estrogens act through estrogen receptor-mediated processes and show no antiestrogenicity in cultured breast cancer cells. Environmental Health Perspectives 102, 572-578.

Mäkelä SI, Pylkkänen LH, Santti RSS \& Adlercreutz H (1995) Dietary soybean may be antiestrogenic in male mice. Journal of Nutrition 125, 437-445.

Makishima M, Honma Y, Hozumi M, Nagata N \& Motoyoshi K (1993) Differentiation of human monoblastic leukemia U837 cells induced by inhibitors of myosin light chain kinase and prevention of differentiation by granulocyte macrophage colony stimulating factor. Biochimica et Biophysica Acta 1176, 245-249.

Markiewicz L, Garey J, Adlercreutz H \& Gurpide E (1993) In vitro bioassays of non-steroidal phytoestrogens. Journal of Steroid Biochemistry and Molecular Biology 45, 399-405.

Martin ME, Haourigui M, Pelissero C, Benassayag C \& Nunez EA (1996) Interactions between phytoestrogens and human sex steroid binding protein. Life Sciences 58, 429-436.

Martin PM, Horwitz KB, Ryan DS \& McGuire WL (1978) Phytoestrogen interaction with estrogen receptors in human breast cancer cells. Endocrinology 103, 1860-1867.

Matsukawa Y, Marui N, Sakai T, Satomi Y, Yoshida M, Matsumoto K, Nishimo H \& Aoike A (1993) Genistein arrests cell cycle progression at G2-M. Cancer Research 53, 1328-1331.

Mayr U, Butsch A \& Schneider S (1992) Validation of two in vitro test systems for estrogenic activities with zearalenone, phytoestrogens and cereal extracts. Toxicology 74, 135-149.

Meeker DR \& Kesten HD (1941) Effect of high protein diets on experimental atherosclerosis of rabbits. Archives of Pathology 31, 147-162.

Menon LG, Kuttan R, Nair MG, Chang Y-C \& Kuttan G (1998) Effect of isoflavones genistein and daidzein in the inhibition of lung metastasis in mice induced by B16F-10 melanoma cells. Nutrition and Cancer 30, $74-77$.

Messina M (1995) Isoflavone intakes by Japanese were overestimated (letter to the editor). American Journal of Clinical Nutrition 62, 645 .

Messina M, Persky V, Setchell KDR \& Barnes S (1994) Soy intake and cancer risk: a review of the in vitro and in vivo data. Nutrition and Cancer 21, $113-131$.

Messina MJ \& Barnes S (1991) The role of soy products in reducing risk of cancer. Journal of the National Cancer Institute 83, $541-546$

Migliaccio S, Davis VL, Gibson MK, Gray TK \& Korach KS (1992) Estrogens modulate the responsiveness of osteoblast-like cells (ROS 17/2.8) stably transfected with estrogen receptor. Endocrinology 130, 2617-2624.

Miksicek RJ (1993) Commonly occurring plant flavonoids have estrogenic activity. Molecular Pharmacology 44, $37-43$.

Miksicek RJ (1994) Interaction of naturally occurring nonsteroidal estrogens with expressed recombinant human estrogen receptor. Journal of Steroid Biochemistry and Molecular Biology 49, 153-160.

Mitchell JH \& Collins AR (1998) Effects of soy milk supplement on oxidative DNA damage in men: a pilot study. COST 916 Workshop, April 17-18. The Netherlands.

Moorghen M, Orde M, Finney KJ, Appleton DR \& Watson AJ (1998) Sulindac enhances cell proliferation in DMHtreated mouse colonic mucosa. Cell Proliferation 31, 59-70.

Morton MS, Matos-Ferreira A, Abranches-Monteiro L, Correia R, Blacklock N, Chan PSF, Cheng C, Lloyd S, Chiehping W \& Griffiths K (1997) Measurement and metabolism of isoflavonoids and lignans in human male. Cancer Letters 114, 145-151.

Murillo G, Singletary KW, Kamath SK \& Arjmandi BH (1998) The antitumorigenic properties of ipriflavone and genistein in rat mammary tissues. FASEB Journal 12, A828 Abstr. no. 4801.

Murphy CT, Kellie S \& Westwick J (1993) Tyrosine-kinase activity in rabbit platelets stimulated with plateletactivating factor. The effect of inhibiting tyrosine kinase with genistein on platelet-signal-molecule elevation and functional responses. European Journal of Biochemistry 216, 639-651. 
Murrill WB, Brown NM, Zhang J-X, Manzolillo PA, Barnes S \& Lamartiniere CA (1996) Prepubertal genistein exposure suppresses mammary cancer and enhances gland differentiation in rats. Carcinogenesis 17, $1451-1457$.

Nagata C, Takatsuka N, Kurisu Y \& Shimizu H(1998) Decreased serum total cholesterol concentration is associated with high intake of soy products in Japanese men and women. Journal of Nutrition 128, 209-213.

Naik HR, Lehr JE \& Pienta KJ (1994) An in vitro and in vivo study of antitumor effects of genistein on hormone refractory prostate cancer. Anticancer Research 14, 2617-2620.

Nemere I (1995) Non-genomic effects of 1,25-dihydroxyvitamin $\mathrm{D}_{3}$ : potential relation of a plasmalemmal receptor to the acute enhancement of intestinal calcium transport in chick. Journal of Nutrition 125, 1695S-1698S.

Nemere I (1996) Apparent non-nuclear regulation of intestinal phosphate transport: effects of 1,25-dihydroxyvitamin $\mathrm{D}_{3}, 24,25$ - dihydroxyvitamin $\mathrm{D}_{3}$, and 25-hydroxyvitamin $\mathrm{D}_{3}$. Endocrinology 137, 2254-2261.

Nestel PJ, Yamashita T, Sasahara T, Pomeroy S, Dart A, Komesaroff P, Owen A \& Abbey M (1997) Soy isoflavones improve systemic arterial compliance but not plasma lipids in menopausal and perimenopausal women. Arterisclerosis, Thrombosis and Vascular Biology 17, 3392-3398.

Nomura A, Henderson BE \& Lee J (1978) Breast cancer and diet among the Japanese in Hawaii. American Journal of Clinical Nutrition 31, 2025-2030.

Oishi K, Okada K, Yoshida O, Yamabe H, Ohno Y, Hayes RB \& Schroeder FH (1988) A case control study of prostatic cancer with reference to dietary habits. Prostate 12, 179-190.

Okura A, Arakawa H, Oka H, Yoshinari T \& Monden Y (1988) Effect of genistein on topoisomerase activity and the growth of val 12 H-ras-transformed NIH3T3 cells. Biochemical and Biophysical Research Communications 157, $183-189$.

Olsson H, Landin-Olsson M \& Gullberg B (1983) Retrospective assessment of menstrual cycle length in patients with breast cancer, in patients with benign breast disease, and in women without breast disease. Journal of the National Cancer Institute 70, 17-20.

Onoe Y, Miyaura C, Ohta H, Nozawa S \& Suda T (1997) Expression of estrogen receptor $\beta$ in rat bone. Endocrinology 138, 4509-4512.

Paech K, Webb P, Kuiper GG, Nilsson S, Gustafsson J, Kushner PJ \& Scanlan TS (1997) Differential ligand activation of estrogen receptors ERalpha and ERbeta at AP1 sites. Science 277, 1508-1510.

Pagliacci MC, Smacchia M, Migliorati G, Grignana F, Riccardi C \& Nicoletti I (1994) Growth-inhibitory effects of the natural phytoestrogen genistein in MCF-7 human breast cancer cells. European Journal of Cancer 30A, $1675-1682$.

Pansini F, Bonaccorsi G, Albertazzi P, Costantino D, Valerio A, Negri C, Ferrazzini S, Bonocuore I, De Aloysio D, Fontana A, Pansini N \& Mollica G (1997) Soy phytoestrogens and bone. Annual Meeting of the North American Menopause Society, p. 44, Abstr. no. 97.061.

Peterson G \& Barnes S (1991) Genistein inhibits of the growth of human breast cancer cells: independence from estrogen receptors and the multi-drug resistance gene. Biochemical and Biophysical Research Communications 179, $661-667$.

Peterson G \& Barnes S (1993) Genistein and biochanin A inhibit the growth of human prostate cancer cells but not epidermal growth factor receptor autophosphorylation. The Prostate 22, 335-345.

Peterson G \& Barnes S (1996) Genistein inhibits both estrogen and growth factor-stimulated proliferation of human breast cancer cells. Cell Growth and Differentiation 7, 1345-1351.

Peterson TG, Kim H \& Barnes S (1998) Genistein may inhibit the growth of human mammary epithelial (HME) cell by augmenting by transforming growth factor beta $(\mathrm{TGF} \beta)$ signaling. American Journal of Clinical Nutrition 68, Suppl., $1527 \mathrm{~S}-1528 \mathrm{~S}$

Petrakis NL, Barnes S, King EB, Lowenstein J, Wiencke J, Lee MM, Miike R, Kirk M \& Coward L (1996) Stimulatory influence of soy protein isolate on breast secretion in pre- and postmenopausal women. Cancer Epidemiology, Biomarkers \& Prevention 5, 785-794.

Pettersson K, Grandien K, Kuiper GG \& Gustafsson JA (1997) Mouse estrogen receptor beta forms estrogen response element-binding heterodimers with estrogen receptors alpha. Molecular Endocrinology 11, 1486-1496.

Picotto G, Massheimer V \& Boland R (1996) Acute stimulation of intestinal cell calcium influx induced by $17 \beta$ oestradiol via the cAMP messenger system. Molecular and Cellular Endocrinology 119, 129-134.

Pienta KJ \& Esper PS (1993) Risk factors for prostate cancer. Annals of Internal Medicine 118, 793-803.

Pollard M \& Luckert PH (1997) Influence of isoflavones in soy protein isolates on development of induced prostaterelated cancers in L-W rats. Nutrition and Cancer 28, 41-45.

Potter SM, Baum JA, Teng H, Stillman RJ \& Erdman JW Jr (1998) Soy protein and isoflavones: Their effects on blood lipids and bone density in postmenopausal women. American Journal of Clinical Nutrition 68, 1375S-1379S.

Potter SM, Jimenez-Flores R, Pollack J-A, Lone TA \& Berber- Jiminez MD (1993) Protein-saponin interaction and its influence on blood lipids. Journal of Agricultural and Food Chemistry 41, 1287-1291.

Ramakrishna MBV, Mital BK, Gupta KC \& Sand NK (1989) Determination of phenolic acids in different soybean varieties by reversed phase high performance liquid chromatography. Journal of Food Science and Technology 26, $154-155$.

Rao AV \& Janezic SA (1992) The role of dietary phytosterols in colon carcinogenesis. Nutrition and Cancer 18, 43 -52.

Rauth S, Kichina J \& Green A (1997) Inhibition of growth and induction of differentation of metastatic melanoma cells in vitro by genistein: chemosensitivity is regulated by cellular p53. British Journal of Cancer 75, 15591566. 
Register TC, Anthony M, Jayo MJ \& Williams JK (1997) Effects of $17 \beta$-oestradiol and consumption of phytoestrogenrich soy or casein/lactalbumin-based diets on serum chemistries in ovariectomized female macaques. Journal of Bone and Mineral Research 12 Suppl. 1, S350 Abstr. no. F498.

Ross RK, Bernstein LA, Lobo RA, Shimizu H, Stanczyk FZ, Pike MC \& Henderson BE (1992) 5-alpha-reductase activity and risk of prostate cancer among Japanese and US white and black males. Lancet 339, 887-889.

Ruiz-Larrea MB, Mohan AR, Paganga G, Miller NJ, Bolwell GP \& Rice-Evans CA (1997) Antioxidant activity of phytoestrogenic isoflavones. Free Radical Research 26, 63-70.

Santell RC, Chang YC, Nair MG \& Helferich WG (1997) Dietary genistein exerts estrogen effects upon the uterus, mammary gland and the hypothalmic/pituitary axis in rats. Journal of Nutrition 127, 263-269.

Santell RC, Kieu N \& Helferich WG (1998) The effect of genistein upon estrogen receptor negative human breast cancer cell growth in vitro and in vivo. FASEB Journal 12, A655 Abstr. no. 3807.

Santibáñez JF, Navarro A \& Martinez J (1997) Genistein inhibits proliferation and in vitro invasive potential of human prostatic cancer cell lines. Anticancer Research 17, 1199-1204.

Sathyamoorthy N \& Wang TTY (1997) Differential effects of dietary phytoestrogen daidzein and equol on human breast cancer MCF-7 cells. European Journal of Cancer 33, 2384-2389.

Schleicher T, Zheng M, Zhang M \& Lamartiniere CA (1998) Genistein inhibition of prostate cancer cell growth and metastasis in vivo. American Journal of Clinical Nutrition 68, Suppl., 1526S Abstr.

Scholar EM \& Toewa ML (1994) Inhibition of invasion of murine mammary carcinoma cells by the tyrosine kinase inhibitor genistein. Cancer Letters 87, 159-162.

Severson KJ, Nomura AMY, Grove JS \& Stemmermann GN (1989) A prospective study of demographics, diet, and prostate cancer among men of Japanese ancestry in Hawaii. Cancer Research 49, 1857-1860.

Shao Z-M, Alpaugh ML, Fontana JA \& Barsky SH (1998) Genistein inhibits proliferation similarly in estrogen receptor-positive and negative human breast carcinoma cell lines characterized by P21 ${ }^{\text {WAF1/CIPI }}$ induction, G2/M arrest, and apoptosis. Journal of Cellular Biochemistry 69, 44-54.

Shibata A, Whittemore AS, Imai K, Kolonel LN, Wu AH, John EM, Stamey TA \& Paggenbarger RS (1997) Serum levels of prostate specific antigen among Japanese-American and native Japanese men. Journal of the National Cancer Institute 89, 1716-1720.

Shimokado K, Umezawa K \& Ogata J (1995) Tyrosine kinase inhibitors inhibit multiple steps of the cell cycle of vascular smooth muscle cells. Experimental Cell Research 220, 266-273.

Shimokado K, Yokota T, Umezawa K, Sasaguri T \& Ogata J (1994) Protein tyrosine kinase inhibitors chemotaxis of vascular smooth muscle cells. Arteriosclerosis and Thrombosis 14, 973-981.

Sonn TT, Hendrich S \& Murphy PA (1997) Estrogenic activity of glycitein, a soy isoflavone. FASEB Journal 11, A601 Abstr. no. 3472.

Spinozzi F, Pagliacci MC, Migliorati G, Moraca R, Grionani F, Riccardi C \& Nicoletti I (1994) The natural tyrosine kinase inhibitor genistein produces cell cycle arrest and apoptosis in Jurkat T-leukemia cells. Leukemia Research 18, $431-439$.

Stephens FO (1997) Phytoestrogens and prostate cancer: possible preventive role. Medical Journal of Australia 167, $138-140$.

Sugano M \& Koba K (1993) Dietary protein and lipid metabolism: a multifunctional effect. Annals of the New York Academy of Sciences 676, 215-222.

Thorburn J \& Thorburn T (1994) The tyrosine kinase inhibitor, genistein, prevents $\alpha$-adrenergic-induced cardiac muscle cell hypertrophy by inhibiting activation of the Ras-MAP kinase signalling pathway. Biochemical and Biophysical Research Communications 202, 1586-1591.

Tobe H, Komiyama O, Komiyama Y \& Maruyama HB (1997) Daidzein stimulation of bone resorption in pit formation assay. Bioscience, Biotechnology and Biochemistry 61, 370-371.

Tovar-Palacio C, Potter SM, Hafermann JC \& Shay NF (1998) Intake of soy protein and soy protein extracts influences lipid metabolism and hepatic gene expression in gerbils. Journal of Nutrition 128, 839-842.

Troll W, Wiesner R, Shellabarger CJ, Hotzman S \& Stone JP (1980) Soybean diet lowers breast tumor incidence in irradiated rats. Carcinogenesis 1, 469-472.

Tsutsumi N (1995) Effect of coumestrol on bone metabolism in organ culture. Biological and Pharmaceutical Bulletin 18, $1012-1015$.

Umayahara Y, Kawamori R, Watada H, Imano E, Iwama N, Morishima T, Yamasaki Y, Kajimoto Y \& Kamada T (1994) Estrogen regulation of the insulin-like growth factor 1 gene transcription involves an AP-1 enhancer. Journal of Biological Chemistry 269, 16433-16442.

Wang H-j \& Murphy PA (1994) Isoflavone content in commercial soybean foods. Journal of Agricultural and Food Chemistry 42, 1666-1673.

Wang TY, Sathyamoorthy N \& Phang JM (1996) Molecular affects of genistein on estrogen receptor mediated pathways. Carcinogenesis 17, 271-275.

Wang W, Higuchi CM \& Zhang R (1997) Individual and combinatory effects of soy isoflavones on the in vitro potentiation of lymphocyte activation. Nutrition and Cancer 29, 29-34.

Wang Y, Heston DWD \& Fair WB (1995) Soy isoflavones decrease the high-fat promoted growth of human prostate cancer. Results of in vivo and animal studies. Journal of Urology 153, Abstr. no. 161.

Watson CS, Pappas TC \& Gametchu B (1995) The other estrogen receptor in the plasma membrane: implications for the actions of environmental estrogens. Environmental Health Perspectives 103, Suppl. 7, 41-50. 
Wei H, Wei L, Frenkel K, Bowen R \& Barnes S (1993) Inhibition of tumor promoter-induced hydrogen peroxide formation in vitro and in vivo by genistein. Nutrition and Cancer 20, 1-12.

Williams JP, Jordan SE, Barnes S \& Blair HC (1998) Tyrosine kinase inhibitor effects on osteoclastic acid transport. American Journal of Clinical Nutrition 68, 1369S-1374S.

Weisz A \& Rosales R (1990) Identification of an estrogen response element upstream of the human c-fos gene that binds the estrogen receptor and the AP-1 transcription factor. Nucleic Acids Research 18, 5097-5106.

Witztum JL \& Steinberg D (1991) Role of oxidized low density lipoprotein in atherogenesis. Journal of Clinical Investigation 88, 1785-1792.

Wrensch MR, Petrakis NL, King EB, Mike R, Mason L, Chew KL, Lee MM, Ernster VL, Hilton JF, Schweitzer R, Goodson WH, III \& Hunt TK (1991) Breast cancer incidence in women with abnormal cytology in nipple aspirates of breast fluid. American Journal of Epidemiology 135, 130-141.

Wu A \& Pike MC (1995) Dietary soy protein and hormonal status. American Journal of Clinical Nutrition 62, $151-$ 152.

Wu AH, Ziegler RG, Horn-Ross PL, Nomura AMY, West DW, Kolonel L, Rosenthal JF, Hoover RN \& Pike MC (1996) Tofu and risk of breast cancer in Asian-Americans. Cancer Epidemiology, Biomarkers, and Prevention 5, 901-906.

Wu AH, Ziegler RG, Horn-Ross PL, Nomura AMY, West DW, Kolonel L, Rosenthal JF, Hoover RN \& Pike MC (1998) Soy intake and risk of breast cancer in Asians and Asian Americans. American Journal of Clinical Nutrition 68, $1437 \mathrm{~S}-1443 \mathrm{~S}$

Xu X, Harris KS, Wang H-J, Murphy PA \& Hendrich S (1995) Bioavailability of soybean isoflavones depends upon gut microflora in women. Journal of Nutrition 125, 2307-2315.

Xu X, Wang HJ, Murphy PA, Cook L \& Hendrich S (1994) Daidzein is a more bioavailable soymilk isoflavone than is genistein in adult women. Journal of Nutrition 124, 825-832.

Yan L, Yee JA, Li D \& McGuire MH (1998) Effect of dietary supplementation of isoflavones on pulmonary metastasis of melanoma cells in mice. FEBS Journal 12, A829 Abstr. no. 4804.

Yan L, Yee JA, McGuire MH \& Graef GL (1997) Effect of dietary supplementation of soybeans on experimental metastasis of melanoma cells in mice. Nutrition and Cancer 29, 1-8.

Yanighara K, Ito A, Toge T \& Numoto M (1993) Antiproliferative effect of isoflavones on human cancer cell lines established from the gastrointestinal tract. Cancer Research 53, 5815-5821.

Yatani R, Kusano I, Shiraishi T, Hayashi T \& Stemmerman GN (1989) Latent prostatic carcinoma: pathological and epidemiological aspects. Japanese Journal of Clinical Oncology 19, 319-326.

Yuan J-M, Wang Q-S, Ross RK, Henderson BE \& Yu MC (1995) Diet and breast cancer in Shanghai and Tianjin, China. British Journal of Cancer 71, 1353-1358.

Yuan J-M, Yu MC, Ross RK, Gao Y-T \& Henderson BE (1988) Risk factors for breast cancer in Chinese women in Shanghai. Cancer Research 48, 1949-1953.

Zava DT \& Duwe G (1997) Estrogenic and antiproliferative properties of genistein and other flavonoids in human breast cancer cells in vitro. Nutrition and Cancer 27, 31-40.

Zhang JX, Hallmans G, Landstrom M, Bergh A, Damber J-E, Aman P \& Adlercreutz H (1997a) Soy and rye diets inhibit the development of Dunning R3327 prostatic adenocarcinoma in rats. Cancer Letters 114, 313-314.

Zhang R, Li Y \& Wang W (1997b) Enhancement of immune function in mice fed high doses of soy daidzein. Nutrition and Cancer 29, 24-28.

Zhou J-R, Mukherjee P, Clinton SK \& Blackburn GL (1998) Soybean components inhibit the growth of human prostate cancer cell line LNCaP in SCID mice via alteration in cell apoptosis, angiogenesis and proliferation. FASEB Journal 12, A658 Abstr. no. 3822. 